DIW BERLIN

Discussion

Papers

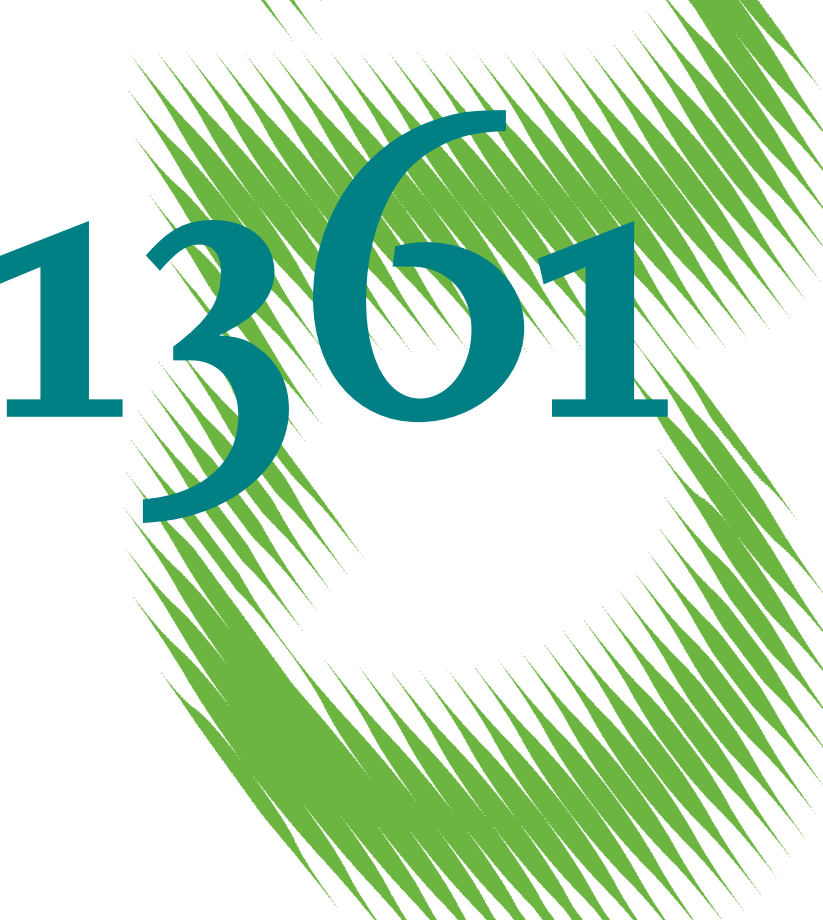

Stated and Revealed

Heterogeneous Risk Preferences in Educational Choice 
Opinions expressed in this paper are those of the author(s) and do not necessarily reflect views of the institute.

IMPRESSUM

(C) DIW Berlin, 2014

DIW Berlin

German Institute for Economic Research

Mohrenstr. 58

10117 Berlin

Tel. $+49(30) 89789-0$

Fax +49 (30) $89789-200$

http://www.diw.de

ISSN print edition $1433-0210$

ISSN electronic edition 1619-4535

Papers can be downloaded free of charge from the DIW Berlin website:

http://www.diw.de/discussionpapers

Discussion Papers of DIW Berlin are indexed in RePEc and SSRN:

http://ideas.repec.org/s/diw/diwwpp.html

http://www.ssrn.com/link/DIW-Berlin-German-Inst-Econ-Res.html 


\title{
Stated and revealed heterogeneous risk preferences in educational choice ${ }^{1}$
}

\author{
Frank M. Fossen ${ }^{2} \quad$ Daniela Glocker ${ }^{3}$
}

February 3, 2014

\begin{abstract}
:
Stated survey measures of risk preferences are increasingly being used in the literature, and they have been compared to revealed risk aversion primarily by means of experiments such as lottery choice tasks. In this paper, we investigate educational choice, which involves the comparison of risky future income paths and therefore depends on risk and time preferences. In contrast to experimental settings, educational choice is one of the most important economic decisions taken by individuals, and we observe actual choices in representative panel data. We estimate a structural microeconometric model to jointly reveal risk and time preferences based on educational choices, allowing for unobserved heterogeneity in the Arrow-Pratt risk aversion parameter. The probabilities of membership in the latent classes of persons with higher or lower risk aversion are modelled as functions of stated risk preferences elicited in the survey using standard questions. Two types are identified: A small group with high risk aversion and a large group with low risk aversion. The results indicate that persons who state that they are generally less willing to take risks in the survey tend to belong to the latent class with higher revealed risk aversion, which indicates consistency of stated and revealed risk preferences. The relevance of the distinction between the two types for educational choice is demonstrated by their distinct reactions to a simulated tax policy scenario.
\end{abstract}

JEL classification: I20, D81.

Keywords: Educational choice, stated preferences, revealed preferences, risk aversion, time preference.

\footnotetext{
1 Acknowledgement: We would like to thank Giacomo Corneo, Katja Görlitz, Peter Haan, Viktor Steiner, Arthur van Soest, Daniel Sturm, and participants at the Research Seminar at Freie Universität Berlin in November 2013 and at the 2013 Winter Workshop at DIW Berlin for valuable comments. The usual disclaimer applies.

${ }^{2}$ Freie Universität Berlin, DIW Berlin and IZA. Address: Freie Universität Berlin, Boltzmannstr. 20,14195 Berlin, Germany, phone: +49 30838 52510, fax: +49 308384 52510, e-mail: frank.fossen@ fu-berlin.de.

3 Centre for Economic Performance, London School of Economics and Political Science. E-mail: d.glocker@1se.ac.uk
} 



\section{Introduction}

Traditionally, economists estimate preference parameters such as risk attitude and a time discount factor based on observed choices of economic agents and structural utility based models. The choice data used for estimation may be collected from the observation of real world activity, or may be extracted from controlled and incentive-compatible experiments. The latter method, especially if applied in a lab, often gives rise to discussions about external validity, ${ }^{4}$ not least because of the typically small incentives in comparison with the stakes involved in real economic decisions. Another approach, which has become popular among economists more recently, is to directly ask respondents for their preferences and attitudes in a survey. One advantage is that such preference questions can be included in large and representative surveys at relatively low cost, and the response data can flexibly be combined with any other information elicited in the survey, enabling a broad spectrum of possible analyses. However, the relationship between respondents' answers to a non-incentivised survey question and their actual behaviour in the real world, especially when it comes to important decisions with high stakes involved, is an issue of lively debate and an important research topic.

An emerging literature in this context compares survey measures of preferences to preferences revealed in incentivized experiments. Dohmen et al. (2011) consider survey measures of risk attitude used in the German Socio-economic Panel (SOEP), a large, representative household survey. The "general risk question" asks respondents to self-report their willingness to take risks in general on a scale from 0 to 10 . In a field experiment with 450 subjects, the authors contrast the answers to this question with paid lottery choices. ${ }^{5}$ They

\footnotetext{
${ }^{4}$ In the context of social preferences, cf. Levitt and List (2007) and Voors et al. (2012).

${ }^{5}$ In the experiment, participants are asked to take twenty choices between a lottery and a safe option, where the payoff of the safe option varies. This is similar to the experimental design of Holt and Laury (2002), where individuals face a set of binary choices between a low risk and a high risk gamble with the same probabilities but different low and high payoffs. In both approaches, the switching point between the two options provides information about the risk-aversion of the participant. Eckel and Grossman (2002) suggest a different design,
} 
find that the self-reported willingness to take risks is a good predictor of actual risk taking behaviour in the experiment. In a similar vein and also based on the SOEP, Vischer et al. (2013) compare a simple survey measure of self-reported patience with experimentally elicited incentivised intertemporal choices and find that both approaches give consistent results. While these studies increase confidence in the survey measures, it remains a largely open question how stated preferences relate to revealed structural preference parameters governing actual real world economic choices in large stake situations.

To shed more light on this question, in this paper, we study one of the most important and far-reaching decisions taken by young persons, namely the choice to a start university education. This decision involves forecasting and comparing future income streams in the alternatives with and without a university education. The decision context is risky because future income is clearly uncertain, and income risk may differ between university graduates and less educated workers. Therefore, the decision to begin tertiary education involves risk preferences. At the same time, the decision to enrol in university implies a trade-off between foregone labour income during the study period and higher labour income later in life, and thus also depends on time preferences. Based on the SOEP data mentioned above, we estimate a structural microeconometric model of the probability of university enrolment conditional on the expected value and the variance of individually forecasted future after-tax income streams in both alternative career paths. These moments of future income are estimated based on individual information available at the time of the enrolment decision and not on ex-post income realizations, which would bias results (Cunha et al., 2005; Cunha and Heckman, 2007); furthermore, we account for multiple non-random selection. Estimation of the model based on the observed educational choices reveals two core structural preference parameters: The Arrow-Pratt coefficient of constant relative risk aversion (CRRA) and a 
utility discount factor as a time preference parameter. Andersen et al. (2008) stress the importance of eliciting risk and time preferences jointly to avoid biased estimates.

For the first time in a structural model of university enrolment with taxation, and going beyond prior related work by Fossen and Glocker (2011), we allow for unobserved heterogeneity in the risk aversion coefficient. Harrison et al. (2007), for instance, conclude from their field experiments that one should not assume the same attitudes to risk for all individuals in contexts with uncertainty. We identify two latent classes of potential university entrants, one pertaining to a more risk averse and one to a less risk averse type. We specify the individual probability of belonging to one of the two classes as a function of the stated general willingness to take risks. This approach is similar to that of French and Jones (2011), who allow for latent classes with heterogeneous parameters of consumption and time preferences in a structural model of retirement behaviour and specify the probability of belonging to these classes in terms of an index built from three survey questions on a person's stated willingness to work. The results from estimating our university enrolment model indicate that those young persons who self-report a low willingness to take risks in the survey are more likely to belong to the latent class with a higher revealed risk aversion. This indicates consistency between the risk preferences revealed from educational choices and the stated risk preferences in the survey.

The main contributions of our paper to the literature are thus the following. First, the high correspondence of revealed and stated preferences further increases confidence in both, the interpretation of the structural parameter (which is estimated from educational choices, not from an experiment) as revealed risk aversion (and not as reflecting some other features of the data), and the validity of the survey measure of risk preferences. More generally, our approach suggests a new methodology for validating survey measures of preferences based on major economic choices in the real world, without relying on experiments. Looking at this point from the reverse side, the plausibility of heterogeneous preference parameters in 
structural models can be assessed by employing stated preference data using this methodology. In the context of education policy, our contribution is that the estimated structural model of university enrolment can be used to simulate the effects of hypothetical tax reforms or changes in higher education financing schemes on university enrolment rates, taking into account the important heterogeneity in risk aversion of potential students. In an illustrative example, we simulate a hypothetical revenue-neutral flat rate tax scenario, and our estimated model predicts that university enrolment rates would increase significantly among the less risk averse type of potential students in the short run, but not among the more risk averse type. Thus, we suggest that the university enrolment model developed here, which has been cross-checked in the way described, can make policy simulations more accurate and reliable.

There have been attempts in the literature to link stated or experimentally elicited risk preference measures to real outcomes. After having established the predictive power of the self-reported risk preferences for the experimental outcome, Dohmen et al. (2011) proceed by analysing the partial correlations between the stated risk preferences and observed risky behaviours, i.e. holding stocks, doing active sports, self-employment, and smoking, and find positive and significant coefficients. Anderson and Mellor (2008) analyse the relationship between experimentally elicited risk preferences and risky health behaviour and find that their experimental measure of risk aversion is negatively and significantly associated with cigarette smoking, heavy drinking, being overweight or obese, and seat belt non-use. Similarly, Lusk and Coble (2005) report that those with higher experimentally measured risk aversion have a lower propensity to consume a potentially risky product, that is, they are less likely to accept and eat genetically modified food. Considering an outcome most closely related to our study and also based on the SOEP, Hartlaub and Schneider (2012) analyse the impact of the stated willingness to take risks on the intention of 17 to 18 year old high-school students to take up university studies later and find a positive partial correlation. However, these studies cannot 
disentangle risk and time preferences, both of which influence the behaviours analysed; for instance, smoking increases the likelihood of a bad health outcome in the distant future, and education increases expected future earnings. Furthermore, it cannot be ruled out that some of the outcomes considered in these studies, especially in the health domain or the intention to study at university, might suffer from non-random reporting error. Even if this literature shows that stated risk preferences are good predictors of experimentally elicited risk preferences, and both are related to specific risky behaviours, the existing literature lacks evidence of the link between these risk preference measures and structural risk and time preferences, which can be separately identified from major economic decisions in life.

Our microeconometric model is closely related to the literature analysing the effect of uncertainty on investment in tertiary education, which began with the two-period model proposed by Levhari and Weiss (1974). In the first period, individuals choose between education and going to work, and in the second period everybody is working. The return to education is uncertain at the time of the decision, but is revealed at the beginning of the second period. The model predicts that increasing risk, i.e. the variance in the payoff for education, reduces investments in education. Kodde (1986) similarly concludes that uncertainty is a main determinant of the decision to invest in education. Empirical studies include Carneiro et al. (2003), who estimate that reducing uncertainty in returns modestly increases college enrolment, and Hartog and Diaz-Serrano (2007), who find that greater postschooling earnings risk requires higher expected returns. Though, none of these studies consider taxation; in this paper, we let decisions explicitly depend on the after-tax expected value and variance of future income streams, derived through a microsimulation model. Eaton and Rosen (1980), Anderberg and Andersson (2003), Hogan and Walker (2007), and Anderberg (2009) develop theoretical models of education and public policy, including tax policy, which as a key feature consider that education may change the wage risk. 
The remainder of this paper is structured as follows: Section 2 details the structural educational choice model and introduces heterogeneous risk aversion. In section 3, we describe the SOEP data and how the individual streams of future after-tax labour income and income risk in the two alternatives paths with and without a university degree are estimated, accounting for multiple sample selection. In section 4 , we provide the estimation results and discuss the relationship between the revealed and stated risk preferences. As an illustration for an application of our model, we simulate a hypothetical flat rate tax scenario. Section 5 concludes the analysis.

\section{Structural model of educational choice with heterogeneous}

\section{revealed risk aversion}

In this section we introduce our structural microeconometric model of educational choice that includes standard parameters of risk aversion and time preference. One advantage of the structural model is that the estimation of its parameters based on individual panel data with actual choices of university enrolment provides us with revealed risk and time preferences. The model builds on Fossen and Glocker (2011), who assume homogeneous preferences; the main extension to the model in this paper is that we accommodate heterogeneity in risk aversion.

We model the binary choice of recent high-school graduates whether to enrol in university to pursue higher education or not. In a discrete time hazard rate framework in annual steps, the enrolment decision is made every year. The sample "at risk of enrolment" consists of young persons who left high school with a university entrance qualification ${ }^{6}$, have not yet started studying, and are between 18 and 25 years of age, which is the usual age range for university enrolment in Germany. A hazard rate model has the advantage of consistently

${ }^{6}$ Abitur or Fachabitur; we do not distinguish between general universities and universities of applied science. 
taking into account censored spells, which refer to persons not fully observed in the relevant period of their lives, and avoids survivorship bias (e.g., Jenkins, 1995).

The rational choice is based on a comparison of future expected utility in the two career options $s$ with university education $(s=1)$ or without $(s=0)$, which allows the young person to start working right away. ${ }^{7}$ In the model, utility in a given future year depends on after-tax labour income $y$ in the same year, which is forecasted by the high-school graduate ex-ante (this forecasting will be explained in Section 3.2). ${ }^{8}$ We assume a standard utility function with constant relative risk aversion (CRRA). ${ }^{9}$ Lifetime utility of a high school graduate $i$ in a given year of observation $t$ in choice $s \in\{0,1\}$ is the discounted sum of the year specific utilities in each future year $t+\tau$ up to the time horizon $T$, which is reached at retirement age: ${ }^{10}$

$$
\begin{aligned}
& U_{\text {sitj }}=\alpha\left[\left(1-\text { risk }_{S}^{\text {dropout }}\right) \sum_{\tau=0}^{T-a g e_{i t}} \frac{1}{\gamma^{\tau}} \frac{\left(y_{s i, t+\tau}\right)^{1-\rho_{j}}}{1-\rho_{j}}+\right. \\
& \text { risk } \left._{S}^{\text {dropout }} \sum_{\tau=0}^{T-a g e_{i t}} \frac{1}{\gamma^{\tau}} \frac{\left(y_{s i, t+\tau}^{\text {dropout }}\right)^{1-\rho_{j}}}{1-\rho_{j}}\right]+x_{i t}^{\prime} \beta_{s}+\varphi_{s}\left(d_{i t}\right)+\varepsilon_{\text {sitj }} .
\end{aligned}
$$

The lifetime utility function includes the two structural parameters of interest. First, the coefficient of CRRA (Pratt 1964), $\rho$, indicates risk loving agents when $\rho<0$, risk neutrality when $\rho=0$ and risk aversion when $\rho>0$. Second, $\gamma$ is the discount factor for future utility and is interpreted as time preference parameter. If $\gamma=1$, future utility has the same value to the

\footnotetext{
${ }^{7}$ We assume the latter choice involves taking an apprenticeship (if the person has not already finished one) with accordingly lower predicted wages during the first two years. In fact, only $3 \%$ of German high-school graduates neither go to college nor take up an apprenticeship (Heine et al., 2008).

${ }^{8}$ We assume it takes five years to graduate, which is the approximate average in Germany, and that during this time each student receives the officially announced minimum cost of living (565 euro per month during the observation period), which each student is entitled to receive according to German legislation. We simulate whether a student is eligible for means-tested student aid from the government; in this case, half the amount is repaid (interest free) as soon as the borrower's monthly net income exceeds 1040 euro. We assume that noneligible students receive the same transfer during their studies from other sources (usually their parents), but no repayment is required.

${ }^{9}$ CRRA is considered more realistic than constant absolute risk aversion, see for instance Keane and Wolpin (2001), Sauer (2004), Hartog and Vijverberg (2007), and Andersen et al. (2008). We do not model preferences on the timing of the resolution of uncertainty in the sense of Kreps and Porteus (1978) or Epstein and Zin (1989; 1991).

${ }^{10}$ Before 2007, the legal retirement age in Germany was $T=65$ years. In 2007, retirement age for persons born after 1965 was increased to 67 years, which we take into account by increasing $T$ to 67 for all high-school graduates observed in 2007 or later.
} 
individual as present utility; the larger $\gamma$, the more future utility is discounted, which implies that the high-school graduate is increasingly myopic. We consider heterogeneity in risk aversion and model $\rho$ as a random coefficient with an arbitrary discrete distribution. Highschool graduates belong to one of $J$ latent classes $j \in\{1, \ldots, J\}$; the subscript $j$ attached to $\rho$ indicates that this parameter may differ between the groups. The young decision makers are aware of their preferences and thus their class memberships, but these are unobservable to the researcher. We will refer to estimates of the structural parameters $\rho$ and $\gamma$ as revealed preferences.

Future labour income $y_{s i, t+\tau}$ in both career options $s$ are random variables from the perspectives of both, the high-school graduates and the researcher. We assume that potential students know the probability distributions of their future income in both alternatives, but not the future realizations.

Beyond income risk, we assume that high-school graduates are aware of the risks of unemployment and of dropping out of the university. Section 3.2 describes how future income $y_{s i, t+\tau}$ is adjusted for unemployment risk. The dropout risk is assumed to be risk $_{1}^{\text {dropout }}=18 \%$ (estimated by Glocker, 2011), whereas those who do not go to university have a dropout risk of zero. A student who withdraws from university earns $y_{1 i, t+\tau}^{\text {dropout }}$, which is assumed to be $79 \%$ of what he or she would receive as a successful university graduate (Heublein et al., 2003). While unemployment is modelled as an independent year-to-year risk, the dropout risk refers to an entire lifetime income path.

Apart from the future income streams, lifetime utility in the two alternatives may be shifted by observable current characteristics $x_{i t}$ of the high-school graduate at the time of the enrolment decision (for example, parents with higher education may increase the preference 
for higher education to maintain the social status) ${ }^{11}$ and the time elapsed since high-school graduation $d_{i t}$ (the function $\varphi_{s}$ is the baseline hazard, which flexibly accounts for the timing of university enrolment $)^{12}$. The parameter $\alpha$ is the weight of utility from income relative to these other factors in the utility function. Finally, $\varepsilon_{s i t j}$ is the error term that captures any further tastes for the two alternatives, which are known to the individual agents, but unobservable for the researcher and therefore treated as a random variable.

We take the expectation with respect to future income $y$, rewrite the expectation of lifetime utility as a sum of expected utilities for each future year, and for each summand conduct a second-order Taylor approximation around $\mu_{s i, t+\tau}=E\left(y_{s i, t+\tau}\right)$ :

$$
\begin{aligned}
& E\left(U_{\text {sitj }}\right)=\alpha\left[\left(1-\text { risk }_{s}^{\text {dropout }}\right) \sum_{\tau=0}^{T-a g e_{i t}} \frac{1}{r^{\tau}}\left(\frac{\left(\mu_{s i, t+\tau}\right)^{1-\rho_{j}}}{1-\rho_{j}}-\frac{1}{2} \rho_{j}\left(\mu_{s i, t+\tau}\right)^{-\rho_{j}-1} \sigma_{s i, t+\tau}^{2}\right)+\right. \\
& \left.\operatorname{risk}_{s}^{\text {dropout }} \sum_{\tau=0}^{T-a g e_{i t}} \frac{1}{r^{\tau}}\left(\frac{\left(\mu_{s i, t+\tau}^{\text {dropout }}\right)^{1-\rho_{j}}}{1-\rho_{j}}-\frac{1}{2} \rho_{j}\left(\mu_{\text {si, } t+\tau}^{\text {dropout }}\right)^{-\rho_{j}-1} \sigma_{\text {si, } t+\tau}^{2 \text { dropout }}\right)\right]+x_{i t}^{\prime} \beta_{s}+ \\
& \varphi_{s}\left(d_{i t}\right)+\varepsilon_{s i t j},
\end{aligned}
$$

where $\sigma_{s i, t+\tau}^{2}=\operatorname{Var}\left(y_{s i, t+\tau}\right)$. The equation implies that for risk-averse agents, expected lifetime utility decreases with greater variance of income (if $\alpha>0$ and $\mu>0$ ), whereas for riskneutral agents, the variance does not matter.

A high-school graduate enrols in university if expected lifetime utility with tertiary education exceeds the alternative. Be $\delta_{i t}$ a binary indicator that equals 1 if person $i$ in observation year $t$ decides to enrol in university and 0 otherwise. Since the individual membership in a latent class $j$ is unobservable, the probability of observing someone enrolling

\footnotetext{
${ }^{11}$ The vector $x$ includes simulated eligibility for means-tested financial student aid provided by the government, parental education and parental net income (these variables capture possible credit constraints), the age at which the person finished high-school, the high-school grades in math and German, the intention to pursue a university degree at age 17 years, dummy variables indicating the number of siblings, a finished apprenticeship and gender, as well as regional and time dummies.

${ }^{12}$ The baseline hazard is specified by dummy variables for years elapsed since high-school graduation, interacted with a gender dummy variable, which allows for gender differences in the timing of university enrolment. The flexible specification of the baseline hazard accommodates timing issues such as mandatory military service for young men, waiting time to compensate for insufficient grades for university enrolment, gap years to serve in voluntary work programs, etc..
} 
in university is the sum of the enrolment probabilities conditional on each latent class, weighted by the probabilities of each class membership. We use $V_{\text {sitj }}$ to abbreviate the term in square brackets in equation (2). The probability of enrolling in university can then be written as:

$$
\begin{aligned}
& P\left(\delta_{i t}=1\right)=\sum_{j=1}^{J} \pi_{i t j} P\left(E\left(U_{1 i t j}\right)>E\left(U_{0 i t j}\right)\right)=\sum_{j=1}^{J} \pi_{i t j} \Lambda\left(\alpha\left(V_{1 i t j}-V_{0 i t j}\right)+x_{i t}^{\prime} \beta+\right. \\
& \left.\varphi\left(d_{i t}\right)\right),
\end{aligned}
$$

where $\beta=\beta_{1}-\beta_{0}$ and $\Lambda$ is the cumulative distribution function of the error difference $\varepsilon_{0 i t j}-\varepsilon_{1 i t j .}$ If we assume that the error terms $\varepsilon_{s i t j}$ are type-I extreme value distributed and i.i.d., $\Lambda$ is the cumulative logistic distribution function (McFadden, 1973), which leads us to a mixed logit model. This equation shows that $\alpha$ can be interpreted as the coefficient of the differential of the risk-adjusted future income paths in the two alternatives with and without university education, and we expect this differential to increase the probability of university enrolment.

The probabilities $\pi_{i t j}$ of membership in one of the latent classes $j$, which define risk aversion, are allowed to vary with observable characteristics $w_{i t}$. Therefore, we specify the probabilities to follow a multinomial logit model where the coefficients $\kappa_{j}$ of the vector $w_{i t}$ vary by class $j$ (and class $j=1$ is the omitted base category):

$\pi_{i t j}=\frac{e^{\kappa} j^{\prime} w_{i t}}{1+\sum_{l=2}^{J} e^{\kappa l^{\prime} w_{i t}}} f \ddot{u} r j \in\{2, \ldots, J\} ; \pi_{i t 1}=1-\sum_{j=2}^{J} \pi_{i t j}$.

In particular, we are interested in analysing the relationship between stated risk preferences directly provided by the survey respondents and their revealed risk aversion identified by the actual educational choice and the estimated structural parameters $\rho_{j}$ in the decision model. Therefore, $w$ contains two dummy variables indicating whether someone indicates low or high general willingness to take risks in the interviews (see section 3), with medium willingness to take risks as the base category.

The model can be estimated by applying the maximum likelihood method to the likelihood function 


$$
\begin{aligned}
L= & \prod_{i=1}^{N} \prod_{t \in T_{i}}\left(\sum _ { j = 1 } ^ { J } \pi _ { i t j } [ \Lambda ( \alpha ( V _ { 1 i t j } - V _ { 2 i t j } ) + x _ { i t } ^ { \prime } \beta + \varphi ( d _ { i t } ) ) ] ^ { \delta _ { i t } } \left[1-\Lambda\left(\alpha \left(V_{1 i t j}-\right.\right.\right.\right. \\
& \left.\left.\left.\left.V_{2 i t j}\right)+x_{i t}^{\prime} \beta+\varphi\left(d_{i t}\right)\right)\right]^{1-\delta_{i t}}\right)
\end{aligned}
$$

where $T_{i}$ is the set of years in which high-school graduate $i$ is observed in the relevant age range between 18 and 25.

\section{Data and income forecasting}

\subsection{Individual panel data with stated risk preferences}

In this analysis we use the German Socio-economic Panel (SOEP), an annual household panel survey that is representative for the population in Germany. ${ }^{13}$ In 2010 , about 23,000 individuals living in more than 10,000 households were successfully interviewed. This analysis draws on the waves from 2000 to 2010. The first interview with young persons living in surveyed households occurs when they are 17 years old. During this first interview, additional retrospective information about the youth period is elicited, such as school grades. The data also contain information about the parents, such as their education and income, and siblings. These are important control variables in our model of educational choice. The same respondents are followed up every year, even if they leave the household and/or move somewhere else, whenever possible. This enables us to track most high-school graduates till they enter university (if they do); however, the hazard rate model we employ also consistently accounts for censored spells and thus for possible sample attrition.

Besides the rich background information, another key advantage of the SOEP is that it includes questions that directly measure risk preferences and which have been tested

\footnotetext{
${ }^{13}$ The central aim of the SOEP is to collect representative microdata about individuals and households. It is similar to the PSID (Panel Study of Income Dynamics) in the USA and the BHPS (British Household Panel Survey) in the UK. A stable set of core questions appears every year, covering population and demography; education, training, and qualification; labour market and occupational dynamics; earnings, income, and social security; housing; health; household production; and basic orientation. Wagner et al. (2007) provide a detailed description of the SOEP.
} 
experimentally. In several survey waves (2004, 2006, and every year since 2008) respondents were asked to indicate their general willingness to take risks on an 11-point scale, from 0 to 10, where 0 means "fully unwilling to take risks", and 10 means "fully willing to take risks". ${ }^{14}$ In their field experiment, Dohmen et al. (2011) find that the measure of the willingness to take risks in the SOEP is a good predictor of actual risk-taking behaviour. ${ }^{15} \mathrm{We}$ will refer to this survey measure as stated risk preferences. Figure 1 shows a histogram for recent high-school graduates (the sample used to estimate the university enrolment model) and demonstrates that their stated risk preferences vary considerably and spread over the complete spectrum (the pattern for the unrestricted population looks similar, cf. Fossen, 2012). As the questions for risk preferences were included in specific survey waves only, we use the answers of the same respondent in the other survey years as well (where possible, we use answers from further back in time), assuming stability of these preferences over short time periods.

\section{Figure 1: Histogram of the general willingness to take risks for high-school graduates}

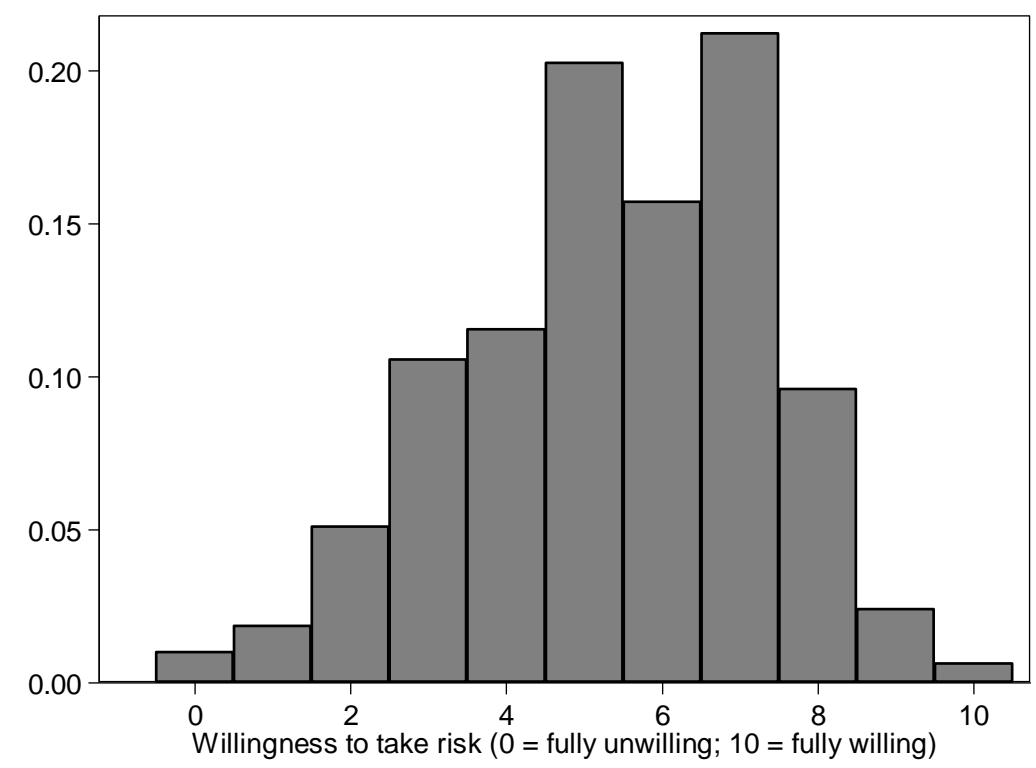

Source: Authors' illustration based on the SOEP (sample of high-school graduates), 2000-2010.

\footnotetext{
${ }^{14}$ The wording in the questionnaire is "Are you generally a person who is fully willing to take risks or do you try to avoid taking risks?"

${ }^{15}$ The SOEP waves of 2004 and 2009 additionally include a measure of risk aversion using lottery choices and questions about risk attitude in specific domains. This paper uses the question about the general willingness to take risks, as this is the only risk question also available in 2006, 2008, and 2010. Furthermore, Dohmen et al. (2011) show that this measure performs better than the lottery measure in predicting behaviour.
} 
To estimate the hazard rate model of university enrolment, we restrict our sample to high-school graduates with a university entrance qualification, who are between ages 18 and 25 and have not (yet) started studying. This sample consists of 2187 person-year observations without missing values in the relevant variables, which refer to 1088 individuals. Thus, the average person remains in the sample "at risk of university enrolment" for about two years, which indicates that most high-school graduates start studying soon after high-school graduation. Table A 1 in the Appendix provides descriptive statistics of the potential university entrants. The full sample of working-age adults between 18 and 65 years of age is used to estimate the expectation and variance of earnings; Table A 2 shows descriptive statistics. All monetary variables are deflated by the Consumer Price Index to prices of 2000.

\subsection{Estimation of future labour income and its risk}

Before the model of university enrolment can be estimated by maximizing the likelihood function (5), the first two moments of future after-tax labour income $y_{s i, t+\tau}$ of each high-school graduate $i$ at each age $t+\tau$ (from the current age $t$ until retirement age) in the two states $s$ (with or without university education) have to be estimated, i.e. the expected value $\mu_{s i, t+\tau}$ and the

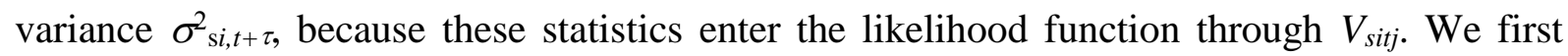
summarize the estimation strategy, which follows Fossen and Glocker (2011), before we provide details concerning the various steps involved.

We assume that high-school graduates form expectations about the distribution of their future income conditional on the two alternative education paths by observing working-age persons in Germany with characteristics similar to their own. Therefore, we use the sample of working-age individuals to estimate regressions of gross (before-tax) income on a vector of demographic and human capital and work-related variables $z_{i t}^{\text {wage }}$ (including a dummy variable indicating a university degree); this allows us to predict the expected value 
conditional on $z_{i t}^{\text {wage }}{ }^{16}$ Based on the squared residuals from the regression, we estimate heteroscedasticity functions with the same characteristics as regressors. This enables us to also predict the variance of earnings conditional on $z_{i t}^{\text {wage }}$. In both regressions we account for multiple non-random sample selection. The estimations are conducted separately for men and women because of the well-documented differences in male and female wage equations. Subsequently, we use the estimated equations to forecast individual profiles of the expected value and variance of income over the life cycle, separately for the two alternative education paths, and apply a microsimulation model to translate the predicted moments of gross income into net (after-tax) predictions. Finally, these net moments are adjusted for unemployment risk, which differs between the two education paths.

Two sources of interdependent selection have to be considered in the earnings and variance regressions (e.g. Fishe et al., 1981). First, a working-age person's educational attainment is not random, and second, we observe earnings only for those who decide to work for money. Therefore, in a first step, we estimate two simultaneous selection equations. The first equation captures the choice of person $i$ observed in year $t$ to be a university graduate:

$I_{1 i t}^{*}=\eta_{1}^{\prime} z_{1 i t}+v_{1 i t} ; I_{1 i t}=1\left(I_{1 i t}^{*}>0\right)$.

The second is the work participation equation:

$I_{2 i t}^{*}=\eta_{2}^{\prime} z_{2 i t}+\iota I_{1 i t}+v_{2 i t} ; \quad I_{2 i t}=1\left(I_{2 i t}^{*}>0\right)$.

$I^{*}$ are latent index variables and $I$ the observed outcome dummy variables. The vector $z_{1 i t}$ includes only bits of information that are available to the person at the time of the enrolment decision, such as high-school grades and parents' education. ${ }^{17} z_{2 i t}$ in the work participation equation is comprised of relevant contemporaneous characteristics, including age, educational

${ }^{16}$ Specifically, $z_{i t}^{\text {wage }}$ is comprised of work experience (in years and years squared), year dummies, 15 federal state dummies, 9 industry dummies, and dummy variables indicating self-employment, a completed apprenticeship, and current service in an apprenticeship, as well as German nationality, physical handicap, and an intercept.

${ }^{17}$ The vector $z_{1 i t}$ consists of the most recent high-school grades in German and math, the degree to which parents showed interest in the high-school graduate's school performance, size of the city in which the young person grew up, parents' high-school degree and employment status (when the respondent was aged 15 years), an indicator whether the parents were born in Germany, as well as an intercept. 
attainment, whether small children are present in the household, and the regional unemployment rate. ${ }^{18}$ The error terms $v_{1 i t}$ and $v_{2 i t}$ may correlate. We estimate a bivariate probit model (Maddala, 1986) and allow for a structural shift by including the outcome of the first selection process $I_{1 i t}$, (university education) as a dummy variable in the work participation equation (Heckman, 1978). This enables us to predict selection correction terms $M$ (similar to the standard inverse Mill's ratio) which enter the expected income and variance regressions in the second step to control for selection (see Fossen and Glocker, 2011, for details). The estimation results for the selection equations appear in Table A 3 in the Appendix.

In the second step we run regressions of hourly gross wages $y_{\text {sit }}^{g}$ on $z_{i t}^{\text {wage }}$ separately for working-age persons with $(s=1)$ and without $(s=0)$ a university degree,

$y_{0 i t}^{g}=\theta_{0}^{\prime} z_{i t}^{\text {wage }}+\lambda_{01} M_{12 i t}+\lambda_{02} M_{21 i t}+u_{0 i t}$, and

$y_{1 i t}^{g}=\theta_{1}^{\prime} z_{i t}^{\text {wage }}+\lambda_{11} M_{34 i t}+\lambda_{12} M_{43 i t}+u_{1 i t}$,

where $u_{s i t}$ are the error terms. To predict the variance of income conditional on individual characteristics, we regress the natural logarithms of the squared residuals from the wage regressions on $z_{i t}^{\text {wage }}$ and the terms $M$ to control for non-random selection, separately by education choice $s$ :

$\ln \left(\hat{u}_{0 i t}^{2}\right)=\xi_{0}^{\prime} z_{i t}^{\text {wage }}+\lambda_{01} M_{12 i t}+\lambda_{02} M_{21 i t}+e_{0 i t}$, and

$\ln \left(\hat{u}_{1 i t}^{2}\right)=\xi_{1}^{\prime} z_{i t}^{\text {wage }}+\lambda_{11} M_{34 i t}+\lambda_{12} M_{43 i t}+e_{1 i t}$

The estimation results for the wage and variance regressions are provided in Table A 4 and Table A 5 in the Appendix.

We use the estimated equations to forecast the individual expected value and variance of annual income over the life cycle until retirement age based on average working hours of men

\footnotetext{
${ }^{18}$ Furthermore, $z_{2 i t}$ includes age squared, unemployment experience (level and square terms), regional and year dummies, and dummy variables indicating whether the individual is married, was born in Germany, or is handicapped, as well as an intercept.
} 
and women in Germany. We assume that in the graduate career path, students spend the first five years at the university and receive monetary transfers as detailed in footnote 8 . From year six on, work experience is increased successively in equation (8) to forecast the income profile over the lifetime. In the alternative non-graduate career path, we assume that people start working right away, but during the first two years, income is lower because young persons take an apprenticeship first. We accommodate this by setting the dummy variable indicating that someone is currently an apprentice in equation (9) to one when predicting the first two years. For the predictions, the other variables in $z_{i t}^{\text {wage }}$ are set according to the aggregate distributions, conditional on age and gender.

Since utility depends on after-tax income, we apply a microsimulation model of the German progressive personal income tax system and the social insurance system to derive net income from predicted gross income. Because we predict labour income for the future of current high-school graduates, some information relevant for taxation at the time when earnings are accrued and taxed, such as marital status and the number of children, are unknown. Therefore, we calculate the net income under the assumption that the person will either be unmarried or married to a spouse with the same gross income (which has the same tax implications for the individual in Germany), and neglect child benefits. We deem plausible that young recent high-school graduates make similar simplifying assumptions when estimating their future taxes.

Finally we adjust the expected value and the variance of net income for unemployment risk, assuming that high-school graduates expect unemployment risk to remain unchanged in the future. We use separate estimates of rates of unemployment $r i s k_{s t}^{\text {unempl }}$ for persons in Germany with and without a university degree (alternative $s$ ) by year $t$ (in which the educational choice is taken) obtained from $\operatorname{OECD}$ (2012, p. 134). In all years in the estimation period, university graduates have lower annual unemployment risks than non-graduates (about $4 \%$ vs. $9 \%$ on average). According to the (moderately simplified) German legislation, an 
unemployed person receives unemployment benefits at the unemployment benefit rate (UBR) of $60 \%$ (67\% for parents) of the net labour income the person received before. We assume that the high-school graduates expect potential unemployment to last no longer than the period during which the unemployment benefit can be received (usually one year). Income adjusted for unemployment risk in a future year $t+\tau$ can thus be written as

$y_{s i, t+\tau}=\left[\left(1-r i s k_{s t}^{\text {unempl }}\right)+r i s k_{s t}^{\text {unempl }} \cdot U B R\right] y_{s i, t+\tau}^{\text {unadjusted }}$,

which allows us to adjust both the expected value and the variance of future income. This yields estimates of $\mu_{s i, t+\tau}$ and $\sigma_{s i, t+\tau}^{2}$, which enter the likelihood function (5).

\section{Structural estimation results and the link to stated preferences}

\subsection{Unobserved heterogeneity in risk aversion}

The results from estimating the structural model of the probability of starting university education appear in Table 1. They are obtained by maximizing the likelihood function (5) based on the sample of recent high-school graduates. The standard errors are robust to heteroscedasticity and clustering at the individual level to account for repeated observations of the same persons. Column (1) shows the logit coefficients from a basic model without any role for income and risk expectations, i.e. the weight of the future income term $\alpha$ is constrained to be zero, and the enrolment probability exclusively depends on the control variables. Column (2) contains the more general model with unconstrained $\alpha$, but imposing homogeneous risk attitude with a freely estimated, but identical coefficient of constant relative risk aversion (CRRA) $\rho$ for everyone in the sample. 
Table 1: Transition to tertiary education: Results with unobserved latent risk aversion types

\begin{tabular}{|c|c|c|c|c|c|c|}
\hline \multirow{4}{*}{$\begin{array}{l}\text { Definition of low willingness to } \\
\text { take risks dummy: } \\
\text { Definition of high willingness to } \\
\text { take risks dummy: }\end{array}$} & \multirow{4}{*}{$\begin{array}{l}\text { (1) } \\
\text { No income } \\
\text { expecta- } \\
\text { tions }\end{array}$} & \multirow{4}{*}{$\begin{array}{l}\text { (2) } \\
\text { Homoge- } \\
\text { neous risk } \\
\text { aversion }\end{array}$} & \multirow{4}{*}{$\begin{array}{l}\text { (3) } \\
\text { Heterogeneo }\end{array}$} & $(4)$ & $(5)$ & \multirow[t]{2}{*}{$(6)$} \\
\hline & & & & us risk aversion & & \\
\hline & & & & $\begin{array}{l}\text { Willingn. to } \\
\text { take risks }<2\end{array}$ & $\begin{array}{l}\text { Willingn. to } \\
\text { take risks }<3\end{array}$ & $\begin{array}{l}\text { Willingn. to } \\
\text { take risks }<4\end{array}$ \\
\hline & & & & $\begin{array}{l}\text { Willingn. to } \\
\text { take risks }>8\end{array}$ & $\begin{array}{l}\text { Willingn. to } \\
\text { take risks > } 7\end{array}$ & $\begin{array}{l}\text { Willingn. to } \\
\text { take risks }>5\end{array}$ \\
\hline \multicolumn{7}{|l|}{ Structural parameters: } \\
\hline Risk (CRRA) coeff. $\rho_{l}$ & & $\begin{array}{l}0.0798 * * \\
(0.0365)\end{array}$ & $\begin{array}{l}0.0870 * \\
(0.0448)\end{array}$ & $\begin{array}{l}0.0691 * \\
(0.0370)\end{array}$ & $\begin{array}{l}0.0736 * * \\
(0.0369)\end{array}$ & $\begin{array}{l}0.0803 * \\
(0.0435)\end{array}$ \\
\hline Risk (CRRA) coeff. $\rho_{2}$ & & & $\begin{array}{l}1.0408 * * * \\
(0.1918)\end{array}$ & $\begin{array}{l}0.6687 * * * \\
(0.1613)\end{array}$ & $\begin{array}{l}0.6236 * * * \\
(0.1359)\end{array}$ & $\begin{array}{l}0.5380 * * * \\
(0.1120)\end{array}$ \\
\hline Time preference coeff. $\gamma$ & & $\begin{array}{l}1.1591 * * * \\
(0.0459)\end{array}$ & $\begin{array}{l}1.1265 * * * \\
(0.0480)\end{array}$ & $\begin{array}{l}1.1412 * * * \\
(0.0420)\end{array}$ & $\begin{array}{l}1.1390 * * * \\
(0.0433)\end{array}$ & $\begin{array}{l}1.1615 * * * \\
(0.0467)\end{array}$ \\
\hline Weight of income term $\alpha$ & & $\begin{array}{l}0.1332 * * \\
(0.0637)\end{array}$ & $\begin{array}{l}0.1014 * \\
(0.0558)\end{array}$ & $\begin{array}{l}0.1258 * * \\
(0.0531)\end{array}$ & $\begin{array}{l}0.1237 * * \\
(0.0549)\end{array}$ & $\begin{array}{l}0.1215^{*} \\
(0.0655)\end{array}$ \\
\hline \multicolumn{7}{|c|}{ Probability model of being type 2 (logit coefficients): } \\
\hline Low willingness to take risks & & & & $\begin{array}{l}16.9150 * * * \\
(1.5239)\end{array}$ & $\begin{array}{l}13.7183 * * * \\
(1.7725)\end{array}$ & $\begin{array}{l}14.0701 * * * \\
(4.0219)\end{array}$ \\
\hline High willingness to take risks & & & & $\begin{array}{l}-11.7234 * * * \\
(1.2860)\end{array}$ & $\begin{array}{l}-0.2612 \\
(5.0472)\end{array}$ & $\begin{array}{l}9.2283 \\
(10.8004)\end{array}$ \\
\hline Constant & & & $\begin{array}{l}-2.2795 * * * \\
(0.7625)\end{array}$ & $\begin{array}{l}-2.0208^{* *} \\
(0.9842)\end{array}$ & $\begin{array}{l}-2.2416^{*} \\
(1.3074)\end{array}$ & $\begin{array}{l}-13.0725^{* * * *} \\
(2.5405)\end{array}$ \\
\hline \multicolumn{7}{|c|}{ Control variables in university entry model (logit coefficients): } \\
\hline Eligible for student aid & $\begin{array}{l}0.2050 \\
(0.2045)\end{array}$ & $\begin{array}{l}0.1656 \\
(0.2060)\end{array}$ & $\begin{array}{l}0.1790 \\
(0.2086)\end{array}$ & $\begin{array}{l}0.1781 \\
(0.2066)\end{array}$ & $\begin{array}{l}0.1798 \\
(0.2065)\end{array}$ & $\begin{array}{l}0.1957 \\
(0.2086)\end{array}$ \\
\hline Student aid $x$ Parental income & $\begin{array}{l}-0.1922 * \\
(0.1054)\end{array}$ & $\begin{array}{l}-0.1846^{*} \\
(0.1061)\end{array}$ & $\begin{array}{l}-0.1842 * \\
(0.1067)\end{array}$ & $\begin{array}{l}-0.1894 * \\
(0.1068)\end{array}$ & $\begin{array}{l}-0.1901 * \\
(0.1071)\end{array}$ & $\begin{array}{l}-0.1880 * \\
(0.1064)\end{array}$ \\
\hline Student aid $x$ State with tuition & $\begin{array}{l}0.2708 \\
(0.2899)\end{array}$ & $\begin{array}{l}0.3177 \\
(0.2946)\end{array}$ & $\begin{array}{l}0.3082 \\
(0.2971)\end{array}$ & $\begin{array}{l}0.3041 \\
(0.2969)\end{array}$ & $\begin{array}{l}0.3047 \\
(0.2962)\end{array}$ & $\begin{array}{l}0.2919 \\
(0.2961)\end{array}$ \\
\hline Parental net income & $\begin{array}{l}0.0864 * * \\
(0.0350)\end{array}$ & $\begin{array}{l}0.0884 * * \\
(0.0349)\end{array}$ & $\begin{array}{l}0.0901 * * \\
(0.0355)\end{array}$ & $\begin{array}{l}0.0900 * * \\
(0.0354)\end{array}$ & $\begin{array}{l}0.0893 * * \\
(0.0353)\end{array}$ & $\begin{array}{l}0.0895 * * \\
(0.0352)\end{array}$ \\
\hline Age at high school graduation & $\begin{array}{l}0.1857 * * * \\
(0.0599)\end{array}$ & $\begin{array}{l}0.2172 * * * \\
(0.0620)\end{array}$ & $\begin{array}{l}0.2177 * * * \\
(0.0623)\end{array}$ & $\begin{array}{l}0.2197 * * * \\
(0.0622)\end{array}$ & $\begin{array}{l}0.2201 * * * \\
(0.0623)\end{array}$ & $\begin{array}{l}0.2164 * * * \\
(0.0625)\end{array}$ \\
\hline Mother holds university degree & $\begin{array}{l}0.2328 * \\
(0.1289)\end{array}$ & $\begin{array}{l}0.2682 * * \\
(0.1306)\end{array}$ & $\begin{array}{l}0.2857 * * \\
(0.1326)\end{array}$ & $\begin{array}{l}0.2839 * * \\
(0.1312)\end{array}$ & $\begin{array}{l}0.2789 * * \\
(0.1308)\end{array}$ & $\begin{array}{l}0.2810 * * \\
(0.1309)\end{array}$ \\
\hline Father holds university degree & $\begin{array}{l}0.3177 * * \\
(0.1257)\end{array}$ & $\begin{array}{l}0.3321 * * * \\
(0.1260)\end{array}$ & $\begin{array}{l}0.3269 * * \\
(0.1274)\end{array}$ & $\begin{array}{l}0.3293 * * * \\
(0.1269)\end{array}$ & $\begin{array}{l}0.3362 * * * \\
(0.1267)\end{array}$ & $\begin{array}{l}0.3226 * * \\
(0.1264)\end{array}$ \\
\hline Intended university when 17 & $\begin{array}{l}0.6720 * * * \\
(0.1401)\end{array}$ & $\begin{array}{l}0.6586 * * * \\
(0.1403)\end{array}$ & $\begin{array}{l}0.6706 * * * \\
(0.1418)\end{array}$ & $\begin{array}{l}0.6708 * * * \\
(0.1414)\end{array}$ & $\begin{array}{l}0.6671 * * * \\
(0.1412)\end{array}$ & $\begin{array}{l}0.6667 * * * \\
(0.1408)\end{array}$ \\
\hline Intended university n.a. & $\begin{array}{l}0.4393 \\
(0.3300)\end{array}$ & $\begin{array}{l}0.4369 \\
(0.3269)\end{array}$ & $\begin{array}{l}0.4370 \\
(0.3312)\end{array}$ & $\begin{array}{l}0.4526 \\
(0.3315)\end{array}$ & $\begin{array}{l}0.4426 \\
(0.3319)\end{array}$ & $\begin{array}{l}0.4396 \\
(0.3296)\end{array}$ \\
\hline Finished apprenticeship & $\begin{array}{l}0.5258 * * \\
(0.2321)\end{array}$ & $\begin{array}{l}0.6542 * * * \\
(0.2411)\end{array}$ & $\begin{array}{l}0.6589 * * * \\
(0.2431)\end{array}$ & $\begin{array}{l}0.6696 * * * \\
(0.2422)\end{array}$ & $\begin{array}{l}0.6646 * * * \\
(0.2420)\end{array}$ & $\begin{array}{l}0.6479 * * * \\
(0.2437)\end{array}$ \\
\hline Fed. State with tuition fees & $\begin{array}{l}-0.0190 \\
(0.1926)\end{array}$ & $\begin{array}{l}-0.0094 \\
(0.1920)\end{array}$ & $\begin{array}{l}-0.0095 \\
(0.1940)\end{array}$ & $\begin{array}{l}-0.0092 \\
(0.1930)\end{array}$ & $\begin{array}{l}-0.0056 \\
(0.1933)\end{array}$ & $\begin{array}{l}0.0041 \\
(0.1934)\end{array}$ \\
\hline Respondent has one sibling & $\begin{array}{l}-0.1395 \\
(0.1425)\end{array}$ & $\begin{array}{l}-0.1493 \\
(0.1432)\end{array}$ & $\begin{array}{l}-0.1598 \\
(0.1448)\end{array}$ & $\begin{array}{l}-0.1611 \\
(0.1442)\end{array}$ & $\begin{array}{l}-0.1555 \\
(0.1440)\end{array}$ & $\begin{array}{l}-0.1579 \\
(0.1441)\end{array}$ \\
\hline More than one sibling & $\begin{array}{l}-0.0559 \\
(0.3443)\end{array}$ & $\begin{array}{l}-0.0176 \\
(0.3436)\end{array}$ & $\begin{array}{l}-0.0206 \\
(0.3456)\end{array}$ & $\begin{array}{l}-0.0078 \\
(0.3459)\end{array}$ & $\begin{array}{l}-0.0002 \\
(0.3466)\end{array}$ & $\begin{array}{l}-0.0127 \\
(0.3456)\end{array}$ \\
\hline \multicolumn{7}{|c|}{ School grade in German at age 17 (Base: Good): } \\
\hline German grade: Very good & $\begin{array}{l}0.5822 * * \\
(0.2602)\end{array}$ & $\begin{array}{l}0.6055 * * \\
(0.2638)\end{array}$ & $\begin{array}{l}0.6088 * * \\
(0.2661)\end{array}$ & $\begin{array}{l}0.6074 * * \\
(0.2656)\end{array}$ & $\begin{array}{l}0.6129 * * \\
(0.2652)\end{array}$ & $\begin{array}{l}0.5723 * * \\
(0.2668)\end{array}$ \\
\hline German grade: Satisfactory & $\begin{array}{l}-0.3019 * * \\
(0.1385)\end{array}$ & $\begin{array}{l}-0.3137 * * \\
(0.1385)\end{array}$ & $\begin{array}{l}-0.3238 * * \\
(0.1399)\end{array}$ & $\begin{array}{l}-0.3162 * * \\
(0.1391)\end{array}$ & $\begin{array}{l}-0.3148 * * \\
(0.1388)\end{array}$ & $\begin{array}{l}-0.3136 * * \\
(0.1386)\end{array}$ \\
\hline German grade: Poor & $\begin{array}{l}-0.2800 \\
(0.2157)\end{array}$ & $\begin{array}{l}-0.3214 \\
(0.2170)\end{array}$ & $\begin{array}{l}-0.3529 \\
(0.2219)\end{array}$ & $\begin{array}{l}-0.3554 \\
(0.2212)\end{array}$ & $\begin{array}{l}-0.3466 \\
(0.2208)\end{array}$ & $\begin{array}{l}-0.3445 \\
(0.2191)\end{array}$ \\
\hline
\end{tabular}


Table 1 continued

\begin{tabular}{|c|c|c|c|c|c|c|}
\hline & $(1)$ & (2) & (3) & (4) & $(5)$ & $(6)$ \\
\hline \multirow[t]{2}{*}{ German grade: N.a. } & $0.9377 *$ & $0.9202 *$ & $0.9423 * *$ & $0.9115^{*}$ & $0.9166^{*}$ & $0.9189 *$ \\
\hline & $(0.4956)$ & $(0.4762)$ & $(0.4724)$ & $(0.4688)$ & $(0.4733)$ & $(0.4744)$ \\
\hline \multicolumn{7}{|c|}{ School grade in math at age 17 (Base: Good): } \\
\hline \multirow[t]{2}{*}{ Math grade: Very good } & $0.5818 * * *$ & $0.6305^{* * *}$ & $0.6416^{* * *}$ & $0.6429 * * *$ & $0.6315^{* * *}$ & $0.6266 * * *$ \\
\hline & $(0.1898)$ & $(0.1906)$ & $(0.1929)$ & $(0.1923)$ & $(0.1916)$ & $(0.1921)$ \\
\hline \multirow[t]{2}{*}{ Math grade: Satisfactory } & -0.1413 & -0.1728 & -0.1753 & -0.1733 & -0.1724 & -0.1695 \\
\hline & $(0.1528)$ & $(0.1539)$ & $(0.1556)$ & $(0.1546)$ & $(0.1545)$ & $(0.1545)$ \\
\hline \multirow[t]{2}{*}{ Math grade: Poor } & $-0.4364 * *$ & $-0.4772 * * *$ & $-0.4997 * * *$ & $-0.4924 * * *$ & $-0.4922 * * *$ & $-0.4841 * * *$ \\
\hline & $(0.1759)$ & $(0.1766)$ & $(0.1793)$ & $(0.1776)$ & $(0.1775)$ & $(0.1778)$ \\
\hline \multirow[t]{2}{*}{ Math grade: N.a. } & $-1.0733 * *$ & $-1.0963 * *$ & $-1.1118 * *$ & $-1.1025^{* *}$ & $-1.1021 * *$ & $-1.1010 * *$ \\
\hline & $(0.5293)$ & $(0.5115)$ & $(0.5096)$ & $(0.5069)$ & $(0.5113)$ & $(0.5114)$ \\
\hline \multicolumn{7}{|l|}{ Region (Base: West) } \\
\hline \multirow{2}{*}{ North } & 0.0627 & 0.0343 & 0.0309 & 0.0319 & 0.0338 & 0.0277 \\
\hline & $(0.1819)$ & $(0.1835)$ & $(0.1844)$ & $(0.1839)$ & $(0.1833)$ & $(0.1837)$ \\
\hline \multirow[t]{2}{*}{ East } & 0.0715 & 0.0115 & -0.0443 & -0.0253 & -0.0179 & -0.0261 \\
\hline & $(0.1618)$ & $(0.1755)$ & $(0.1857)$ & $(0.1840)$ & $(0.1828)$ & $(0.1769)$ \\
\hline \multirow[t]{2}{*}{ South } & $0.2960 * *$ & $0.2944 * *$ & $0.2906^{* *}$ & $0.2926 * *$ & $0.2923 * *$ & $0.2936 * *$ \\
\hline & $(0.1473)$ & $(0.1471)$ & $(0.1482)$ & $(0.1478)$ & $(0.1477)$ & $(0.1475)$ \\
\hline \multirow[t]{2}{*}{ City state } & 0.0161 & -0.0571 & -0.0550 & -0.0625 & -0.0604 & -0.0535 \\
\hline & $(0.2136)$ & $(0.2181)$ & $(0.2188)$ & $(0.2183)$ & $(0.2177)$ & $(0.2182)$ \\
\hline \multicolumn{7}{|c|}{ Years since high-school graduation (Base: Two years): } \\
\hline \multirow[t]{2}{*}{1 year } & $0.9179 * * *$ & $0.8860 * * *$ & $0.8874 * * *$ & $0.8800 * * *$ & $0.8808 * * *$ & $0.8833 * * *$ \\
\hline & $(0.1890)$ & $(0.1894)$ & $(0.1901)$ & $(0.1899)$ & $(0.1898)$ & $(0.1897)$ \\
\hline \multirow[t]{2}{*}{3 years } & $-1.1785 * * *$ & $-1.1493 * * *$ & $-1.1620 * * *$ & $-1.1551 * * *$ & $-1.1520 * * *$ & $-1.1542 * * *$ \\
\hline & $(0.3436)$ & $(0.3437)$ & $(0.3458)$ & $(0.3451)$ & $(0.3448)$ & $(0.3442)$ \\
\hline \multirow[t]{2}{*}{4 years } & $-0.7592 * *$ & $-0.7143 * *$ & $-0.7284 * *$ & $-0.7207 * *$ & $-0.7166 * *$ & $-0.7212 * *$ \\
\hline & $(0.3351)$ & $(0.3380)$ & $(0.3401)$ & $(0.3397)$ & $(0.3392)$ & $(0.3384)$ \\
\hline \multirow[t]{2}{*}{5 years } & $-2.1821 * * *$ & $-2.1115 * * *$ & $-2.1327 * * *$ & $-2.1186^{* * *}$ & $-2.1163 * * *$ & $-2.1224 * * *$ \\
\hline & $(0.6787)$ & $(0.6856)$ & $(0.6871)$ & $(0.6872)$ & $(0.6870)$ & $(0.6849)$ \\
\hline \multicolumn{7}{|c|}{ Male $x$ years since high-school graduation (Base: Male $x$ two years): } \\
\hline \multirow[t]{2}{*}{ Male $x 1$ year } & $-2.4778 * * *$ & $-2.5053 * * *$ & $-2.5362 * * *$ & $-2.5211 * * *$ & $-2.5186 * * *$ & $-2.5167 * * *$ \\
\hline & $(0.2519)$ & $(0.2528)$ & $(0.2554)$ & $(0.2538)$ & $(0.2535)$ & $(0.2537)$ \\
\hline \multirow[t]{2}{*}{ Male $x 3$ years } & -0.3486 & -0.3322 & -0.3895 & -0.3863 & -0.3735 & -0.3681 \\
\hline & $(0.4211)$ & $(0.4222)$ & $(0.4303)$ & $(0.4279)$ & $(0.4266)$ & $(0.4238)$ \\
\hline \multirow[t]{2}{*}{ Male $x 4$ years } & $-0.8920 * *$ & $-0.8504^{*}$ & $-0.8505^{*}$ & $-0.8473 *$ & $-0.8482 *$ & $-0.8479 *$ \\
\hline & $(0.4419)$ & $(0.4433)$ & $(0.4449)$ & $(0.4445)$ & $(0.4440)$ & $(0.4442)$ \\
\hline \multirow[t]{2}{*}{ Male $x 5$ years } & 0.5898 & 0.6499 & 0.6673 & 0.6628 & 0.6652 & 0.6538 \\
\hline & $(0.7384)$ & $(0.7475)$ & $(0.7483)$ & $(0.7485)$ & $(0.7484)$ & $(0.7471)$ \\
\hline Male & $1.3659 * * *$ & $1.2801 * * *$ & $1.2446 * * *$ & $1.2517 * * *$ & $1.2483 * * *$ & $1.2833^{* * *}$ \\
\hline & $(0.1998)$ & $(0.2071)$ & $(0.2126)$ & $(0.2095)$ & $(0.2100)$ & $(0.2074)$ \\
\hline Year dummies & yes & yes & yes & yes & yes & yes \\
\hline Constant & $-5.9227 * * *$ & $-6.5645 * * *$ & $-6.6186 * * *$ & $-6.6370 * * *$ & $-6.6444 * * *$ & $-6.5153 * * *$ \\
\hline & $(1.1756)$ & $(1.2127)$ & $(1.2232)$ & $(1.2160)$ & $(1.2178)$ & $(1.2241)$ \\
\hline Avg. probability of being type 2 & & & 0.093 & $0.139 *$ & $0.166^{* *}$ & $0.146 * *$ \\
\hline & & & $(0.064)$ & $(0.078)$ & $(0.073)$ & $(0.068)$ \\
\hline$\chi^{2}$ & 326.9537 & 323.9246 & 316.1244 & 320.2988 & 321.3229 & 322.3469 \\
\hline Log likelihood & -1108.1246 & -1104.0594 & -1103.0920 & -1102.4487 & -1102.7120 & -1102.4479 \\
\hline $\mathrm{N}$ (person-years) & 2187 & 2187 & 2187 & 2187 & 2187 & 2187 \\
\hline $\mathrm{N}$ (persons) & 1088 & 1088 & 1088 & 1088 & 1088 & 1088 \\
\hline
\end{tabular}

Notes: Mixed logit estimation results for the structural model of entry into university for high-school graduates. Columns (3)-(6) show results for models with unobserved heterogeneity in risk aversion. Stated general willingness to take risks, which is used to estimate the probabilities of being latent type 2 in models (4)-(6), is measured on a scale from 0-10; medium willingness to take risks is the omitted category. Cluster and heteroscedasticity robust standard errors in parentheses. Significance levels: $* \mathrm{p}<0.1, * * \mathrm{p}<0.05, * * * \mathrm{p}<0.01$.

Source: Authors' calculations based on the SOEP (sample of high-school graduates), 2000-2010. 
Columns (3) to (6) present four variants of the full model with heterogeneous risk aversion and $J=2$ latent classes. The optimization algorithm did not converge for models with more than 2 unobserved types. ${ }^{19}$ In column (3), the probability of belonging to the second latent class is estimated as a simple parameter (technically, $w_{i t}$ in eq. (4) consists of a constant only). In the remaining columns, the probability of being type 2 is modelled in a richer way as a function of dummy variables indicating low or high general willingness to take risks as stated in the survey interviews, with medium willingness as the omitted base category. In column (4), the low risk dummy is one for persons reporting a willingness to take risks below 2 (i.e., 0 or 1 on the scale from 0 to 10 ), and the high risk dummy symmetrically indicates values above 8 (i.e., 9 or 10). In columns (5) and (6), the low and high risk categories are defined over successively wider ranges. ${ }^{20}$

The parameter $\alpha$, i.e. the coefficient of the differential of the risk-adjusted future income paths with and without a university education, is positive and significant and similar in the five models where it is freely estimated. This indicates that high-school graduates take their future income into account when deciding whether to take up university studies, and higher future income as a university graduate relative to the alternative career path increases the probability of university enrolment, as expected. The estimated time preference parameter $\gamma$ is significant and stable in these models as well and indicates that the young high-school graduates discount their future utility by about 13 to $16 \%$ per year.

The coefficient of CRRA is positive and significant in all models and for both types, indicating risk aversion. Under the assumption of homogeneous risk aversion (as in Fossen and Glocker, 2011), the point estimate is 0.08 and may seem rather low. From experiments, Holt and Laury (2002) estimate a risk aversion coefficient around 0.3-0.5, and Andersen et al.

\footnotetext{
${ }^{19}$ We use the Newton-Raphson algorithm for the first ten iterations, then switch to the Berndt-Hall-HallHausman algorithm for the next ten iterations, then switch back, and so forth, if necessary.

${ }^{20}$ A specification defining the low risk dummy as willingness to take risks $<4$ and the high risk dummy, symmetrically, as willingness $>6$, does not achieve convergence. Therefore, in column (6), we define the high risk dummy as willingness to take risks $>5$ instead.
} 
(2008) obtain a larger coefficient of CRRA of 0.74 . The agents in our sample may be less risk averse than the population at large because of their particularly young age at the time of their decision about university enrolment; Dohmen et al. (2011) provide some evidence that risk aversion increases with age.

When we allow for heterogeneous risk attitudes, two clearly distinct latent types are detected. The first is characterized by the CRRA coefficient $\rho_{l}$, which is similar to the coefficient assuming homogeneity, and the second type is considerably (and statistically significantly) more risk averse. The point estimate for $\rho_{2}$ is 1.04 in model (3) and thus well above the range reported by Holt and Laury (2002). In model (4), which uses the narrowest definitions for the dummies indicating low and high willingness to take risks, $\rho_{2}$ is 0.67 ; it plausibly decreases to 0.54 as these dummies cover wider ranges of stated risk preferences in columns (5) and (6). The average unconditional probability of being type 2 is predicted to be about $14-17 \%$ and significant in the richer and preferred models (4) to (6), but only $9 \%$ and insignificant in model (3).

In models (4) through (6), young persons who self-report a low willingness to take risks in the survey interviews have a significantly higher probability of being latent type 2 , i.e. the type with larger revealed risk aversion in the university enrolment model, in comparison to those with a medium willingness to take risks (the base category). Those who answer that they have a high willingness to take risks have a significantly lower probability of being the more risk averse type in model (4), while this coefficient is insignificant in models (5) and (6).

The results indicate a remarkable consistency of stated and revealed risk aversion. The revealed coefficients of CRRA are identified by the partial effect of individually forecasted future income risk on the individually observed choices to start university studies. The structural models best explaining the data are those with two latent types, one characterized by significantly higher risk aversion, which means that persons of this type are discouraged 
from tertiary education by high individual forecasted income variance following this choice. The strong accordance of the concepts of revealed risk aversion with the self-reported risk attitude increases confidence in both, the behavioural relevance of the stated risk preference measure and the interpretation of the structural parameters $\rho_{l}$ and $\rho_{2}$ as revealed risk aversion.

Furthermore, the similarity of the estimates in models (4) to (6) indicates that the results are not sensitive with respect to the definitions of categories for stated risk preference. We also estimate model (5) for the subsample of young men and obtain similar results. ${ }^{21}$ As another robustness check, which follows the idea suggested by Eisenhauer et al. (2013), we use the estimated model in column (5) to predict individual transition probabilities. Then we randomly assign synthetic binary transition indicators based on these probabilities; for example, an observation with a predicted transition probability of $40 \%$ is assigned a 1 with $40 \%$ and a 0 with $60 \%$ probability. Next, we re-estimate the model based on these synthetic data. We obtain similar results as in the estimation based on the original data. This test demonstrates that the estimation is able to recover the underlying parameters from the data generation process.

\subsection{Ex-ante classification of risk aversion types based on stated preferences}

In the previous section, we estimated the structural university enrolment model with two latent classes that differ in their CRRA parameter $\rho$ and found that the probability of being the more risk averse type increases for high-school graduates who self-report a low general willingness to take risks in the interview. In this section, we further investigate the relationship between stated and revealed risk attitude by classifying each individual into one of two groups ex-ante based on their stated risk preference and by assessing how the structural $\rho$ differs between the two groups. Formally, before estimating the structural model with $J=2$

\footnotetext{
${ }^{21}$ We choose model (5) for the robustness checks and for the simulations in section 4.3 because of the balanced definition of the dummy variables indicating the willingness to take risks in the type selection model. The log likelihood values in the models (4)-(6) are very similar and thus do not provide guidance as to which of these three model is preferable. For the sample of young women, the optimization algorithm does not converge.
} 
different CRRA coefficients, we set the probability of being type 2 , i.e. $\pi_{i t 2}$ in equation (3), to one for observations who report a willingness to take risks below a certain cut-off value on the scale from $0-10$, and to zero for those at or above this cut-off point; accordingly, we set $\pi_{i t 1}=1-\pi_{i t 2}$. Table 2 presents the estimated structural parameters for all possible cut-off values from 1-10, most notably $\rho_{2}$ and $\rho_{1}$ in the first and second column, respectively. For easier orientation, the first and last row display the results from homogeneous $\rho$, which is identical to model (2) in Table 1; this corresponds to a model with the cut-off value of 0 or 11 , which puts all observations into a single group. We observe that the point estimates for the weight of the income term $\alpha$ and for the time preference coefficient $\gamma$ are stable across all specifications.

Table 2: Transition to tertiary education: Results with risk aversion types ex-ante determined by stated preferences with different cut-off points

\begin{tabular}{|c|c|c|c|c|c|c|}
\hline & \multicolumn{2}{|c|}{$\begin{array}{l}\text { CRRA coeff. } \rho \text { for stated } \\
\text { willingness to take risks... }\end{array}$} & \multirow[b]{2}{*}{$\begin{array}{l}\text { Weight of } \\
\text { income term } \\
\alpha\end{array}$} & \multirow[b]{2}{*}{$\begin{array}{l}\text { Time prefe- } \\
\text { rence coeff. } \\
\gamma\end{array}$} & \multirow[b]{2}{*}{$\chi^{2}$} & \multirow[b]{2}{*}{$\begin{array}{l}\text { Log } \\
\text { likelihood }\end{array}$} \\
\hline & $\begin{array}{l}<\text { cut-off } \\
\text { value }\left(\rho_{2}\right)\end{array}$ & $\begin{array}{l}\geq \text { cut-off } \\
\text { value }\left(\rho_{l}\right)\end{array}$ & & & & \\
\hline Homogeneous $\rho$ & & $\begin{array}{l}0.0798 * * \\
(0.0365)\end{array}$ & $\begin{array}{l}0.1332 * * \\
(0.0637)\end{array}$ & $\begin{array}{l}1.1591 * * * \\
(0.0459)\end{array}$ & 323.9246 & -1104.0594 \\
\hline Cut-off value: 1 & $\begin{array}{l}0.1575 \\
(0.2587)\end{array}$ & $\begin{array}{l}0.0801 * * \\
(0.0366)\end{array}$ & $\begin{array}{l}0.1325 * * \\
(0.0639)\end{array}$ & $\begin{array}{l}1.1581 * * * \\
(0.0471)\end{array}$ & 323.9063 & -1104.0557 \\
\hline Cut-off value: 2 & $\begin{array}{l}0.6128 * * * \\
(0.1512)\end{array}$ & $\begin{array}{l}0.0763 * * \\
(0.0346)\end{array}$ & $\begin{array}{l}0.1361 * * \\
(0.0605)\end{array}$ & $\begin{array}{l}1.1528 * * * \\
(0.0451)\end{array}$ & 324.0037 & -1102.9985 \\
\hline Cut-off value: 3 & $\begin{array}{l}0.5721 * * * \\
(0.1458)\end{array}$ & $\begin{array}{l}0.0784 * * \\
(0.0350)\end{array}$ & $\begin{array}{l}0.1331 * * \\
(0.0598)\end{array}$ & $\begin{array}{l}1.1492 * * * \\
(0.0448)\end{array}$ & 323.9958 & -1103.0340 \\
\hline Cut-off value: 4 & $\begin{array}{l}0.5030 * * * \\
(0.1681)\end{array}$ & $\begin{array}{l}0.0839 * * \\
(0.0425)\end{array}$ & $\begin{array}{l}0.1184 * \\
(0.0679)\end{array}$ & $\begin{array}{l}1.1659 * * * \\
(0.0452)\end{array}$ & 326.0808 & -1102.5053 \\
\hline Cut-off value: 5 & $\begin{array}{l}0.3827 * * \\
(0.1595)\end{array}$ & $\begin{array}{l}0.0834 * * \\
(0.0398)\end{array}$ & $\begin{array}{l}0.1221^{*} \\
(0.0646)\end{array}$ & $\begin{array}{l}1.1642 * * * \\
(0.0436)\end{array}$ & 326.3210 & -1103.2457 \\
\hline Cut-off value: 6 & $\begin{array}{l}0.0268 \\
(0.0757)\end{array}$ & $\begin{array}{l}0.1097 * * \\
(0.0491)\end{array}$ & $\begin{array}{l}0.1272 * \\
(0.0670)\end{array}$ & $\begin{array}{l}1.1535 * * * \\
(0.0514)\end{array}$ & 323.8048 & -1103.8135 \\
\hline Cut-off value: 7 & $\begin{array}{l}0.0780 * * \\
(0.0385)\end{array}$ & $\begin{array}{l}0.0908 \\
(0.0671)\end{array}$ & $\begin{array}{l}0.1311 * * \\
(0.0650)\end{array}$ & $\begin{array}{l}1.1562 * * * \\
(0.0529)\end{array}$ & 323.7504 & -1104.0521 \\
\hline Cut-off value: 8 & $\begin{array}{l}0.0798 * * \\
(0.0365)\end{array}$ & $\begin{array}{l}0.0842 \\
(0.1335)\end{array}$ & $\begin{array}{l}0.1330 * * \\
(0.0641)\end{array}$ & $\begin{array}{l}1.1588 * * * \\
(0.0471)\end{array}$ & 324.0776 & -1104.0592 \\
\hline Cut-off value: 9 & $\begin{array}{l}0.0784 * * \\
(0.0348)\end{array}$ & $\begin{array}{l}-0.0979 \\
(0.1757)\end{array}$ & $\begin{array}{l}0.1438 * * \\
(0.0666)\end{array}$ & $\begin{array}{l}1.1704 * * * \\
(0.0490)\end{array}$ & 323.2416 & -1103.9160 \\
\hline Cut-off value: 10 & $\begin{array}{l}0.0802 * * \\
(0.0378)\end{array}$ & $\begin{array}{l}0.1344 \\
(0.5868)\end{array}$ & $\begin{array}{l}0.1324 * * \\
(0.0669)\end{array}$ & $\begin{array}{l}1.1581 * * * \\
(0.0524)\end{array}$ & 323.9130 & -1104.0587 \\
\hline $\begin{array}{l}\text { Homogeneous } \rho \\
\text { (as in line } 1 \text { ) }\end{array}$ & $\begin{array}{l}0.0798 * * \\
(0.0365)\end{array}$ & & $\begin{array}{l}0.1332 * * \\
(0.0637)\end{array}$ & $\begin{array}{l}1.1591 * * * \\
(0.0459)\end{array}$ & 323.9246 & -1104.0594 \\
\hline $\begin{array}{l}\text { Notes: Estimation } \\
\text { observations are } \\
\text { stated willingness } \\
\text { observations. Sinc } \\
\text { cut-off points. Rob } \\
\text { Source: Authors' }\end{array}$ & esults for tl & $\begin{array}{l}\text { two risk a } \\
\text { gness line in th } \\
\text { gnest tak }\end{array}$ & $\begin{array}{l}1 \text { of entry intc } \\
\text { rsion types ex }\end{array}$ & $\begin{array}{l}\text { university fo } \\
\text {-ante using d }\end{array}$ & $\begin{array}{l}\text { high-scho } \\
\text { ferent cut- }\end{array}$ & $\begin{array}{l}\text { aduates when } \\
\text { values for the } \\
\text { ased on } 2187 \\
\text { se all possible } \\
* * \text { p }<0.01 \text {. } \\
0 .\end{array}$ \\
\hline
\end{tabular}


Figure 2: Stated and revealed risk preferences

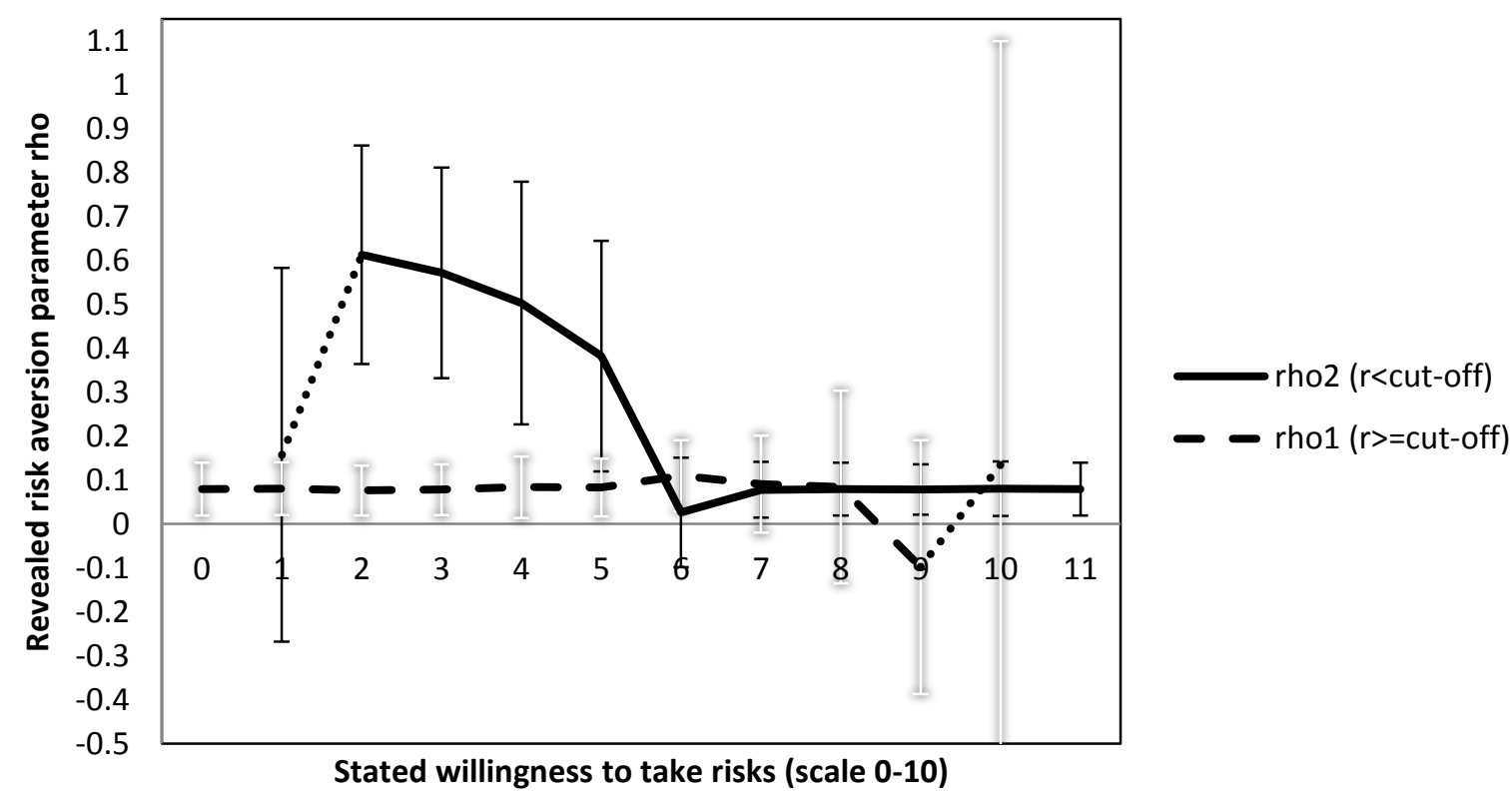

Notes: On the x-axis, the graph spans the stated general willingness to take risks on the 0-10 scale, and on the yaxis, it spans the estimated structural Arrow-Pratt parameter of relative risk aversion, $\rho$ (rho). The solid line corresponds to the first column of Table 2 and shows the estimated revealed $\rho_{2}$ for persons with stated willingness to take risks $r$ below a cut-off point as indicated on the $\mathrm{x}$-axis, while the dashed line (second column of Table 2) is $\rho_{l}$ for individuals with stated $r$ of the cut-off value or above. At the left and right ends of the graph, $\rho$ is estimated for the whole population, because all persons have $r \geq 0$ (left end of the dashed line) and $r<11$ (right end of the solid line). The vertical line segments represent 95\% confidence intervals, which become larger towards the left side for the solid line and towards the right side for the dashed line, where the numbers of observations with the respective stated willingness to take risks become smaller. Note that the leftmost point of the solid line for $r<1$ and the rightmost point of the dashed line for $r \geq 10$ are very imprecisely estimated because of the small number of observations with $r=0$ or $r=10$ (the minimum and maximum values on the scale), as indicated by the wide confidence intervals, so we connect these points with dotted lines only.

Source: Own illustration based on the SOEP, 2000-2010.

The estimated coefficients of risk aversion from these models can more easily be compared in Figure 2. The pattern emerging is that the CRRA parameter $\rho_{2}$, which is revealed from observed education choices of those with stated willingness to take risks below the cutoff value, decreases with higher cut-off values. Thus, the narrower the group of high-school graduates with low risk preference is defined, the higher is their revealed risk aversion coefficient. This again demonstrates the remarkably high consistency between revealed and stated risk preferences. The structural risk aversion parameters of the two groups are statistically different from each other when cut-off points between 2 and 4 are chosen (the confidence bands in the graph do not overlap). For larger cut-off points, the two risk aversion 
types apparently are not separated well from one another, which blurs the difference. ${ }^{22}$ This is also confirmed by the log likelihood values in Table 2, which is largest when the cut-off value 4 is chosen. Note that the log likelihood is even larger in models (4) and (6) in Table 1, where type probabilities are freely estimated. The results from both approaches (free estimation and ex-ante classification of types) consistently indicate that the best models identify a rather small group of more risk-averse high-school graduates, while the majority has a low degree of risk aversion.

\subsection{Resulting heterogeneity in elasticities and responses to tax policy}

How relevant is the identification of the different risk aversion types for the prediction of behavioural responses? In Table 3, we use the structural models estimated in section 4.1 to simulate average changes in the cumulative probability of university enrolment (within five years after graduation from high school) when the expected value or variance of after-tax income in one of the two alternative career paths (with or without a university degree) increases by $10 \% .{ }^{23}$ In column (a), we use the model with homogeneous risk aversion for the simulation, i.e. model (2) from Table 1, whereas in the other columns, we use model (5) with heterogeneous risk aversion. Column (b) presents the average changes in the enrolment probability using the individual probabilities of being one of the two latent types, conditional on the observed variables, whereas columns (c) and (d) show the counterfactual results pretending that everybody were type 1 or the more risk averse type 2 , respectively. For example, the first table row demonstrates that an increase in expected net income in the path with a university education by $10 \%$ increases the average cumulative enrolment probability by $8.2 \%$ in the model with homogeneous risk aversion (which implies an elasticity of about 0.82 ), and by $8.7 \%$ in the model with heterogeneous risk aversion. The respective figures in

\footnotetext{
${ }^{22}$ For cut-off point 1 , the standard error is very large $(0.2587)$, presumably because of the small number of observations with zero willingness to take risks, so this point estimate cannot be interpreted meaningfully.

${ }^{23}$ For these simulations we evaluate the cumulative failure function, which is derived from the estimated hazard rate model, for each observation in the sample of high-school graduates.
} 
the two rightmost columns show that the change is larger for the less risk averse type 1 than for type 2. Note that in the simulations we hold everything else constant; in row 1 that is future income in the alternative path without a university degree and income risk in both paths. Standard errors are obtained by bootstrapping, taking into account clustering on the individual level.

Table 3: Elasticities (x10) of university enrolment with respect to after-tax income and risk

\begin{tabular}{|c|c|c|c|c|}
\hline & (a) & (b) & (c) & (d) \\
\hline & $\begin{array}{l}\text { Homogeneous } \\
\text { risk aversion }\end{array}$ & \multicolumn{3}{|c|}{ Heterogeneous risk aversion } \\
\hline & & Baseline & \multicolumn{2}{|c|}{ Counterfactual simulations } \\
\hline & & $\begin{array}{l}\text { Using actual } \\
\text { type probabili- } \\
\text { ties }\end{array}$ & $\begin{array}{l}\text { Everybody is } \\
\text { type } 1 \text { (low } \\
\text { risk aversion) }\end{array}$ & $\begin{array}{l}\text { Everybody is } \\
\text { type } 2 \text { (high risk } \\
\text { aversion) }\end{array}$ \\
\hline \multicolumn{5}{|l|}{ Increase by $10 \%$ of... } \\
\hline$\ldots$ net income for graduates & $\begin{array}{l}8.177 * * \\
(3.506)\end{array}$ & $\begin{array}{l}8.678 * * * \\
(3.037)\end{array}$ & $\begin{array}{l}9.012 * * * \\
(3.274)\end{array}$ & $\begin{array}{l}6.761 * * * \\
(2.363)\end{array}$ \\
\hline ... net income for non-graduates & $\begin{array}{l}-7.562 * * * \\
(2.929)\end{array}$ & $\begin{array}{l}-7.954 * * * \\
(2.502)\end{array}$ & $\begin{array}{l}-8.042 * * * \\
(2.584)\end{array}$ & $\begin{array}{l}-7.425^{* * * *} \\
(2.161)\end{array}$ \\
\hline $\begin{array}{l}\ldots \text { variance of net income for } \\
\text { graduates }\end{array}$ & $\begin{array}{l}-0.061 \\
(0.115)\end{array}$ & $\begin{array}{l}-0.107 \\
(0.107)\end{array}$ & $\begin{array}{l}-0.064 \\
(0.104)\end{array}$ & $\begin{array}{l}-0.326 * * \\
(0.145)\end{array}$ \\
\hline $\begin{array}{l}\text { graduates } \\
\text {... variance of net income for }\end{array}$ & $\begin{array}{l}(0.115) \\
0.115\end{array}$ & $\begin{array}{l}(0.107) \\
0.243 *\end{array}$ & $\begin{array}{l}(0.104) \\
0.107\end{array}$ & $\begin{array}{l}(0.145) \\
0.971 * * *\end{array}$ \\
\hline non-graduates & $(0.124)$ & $(0.136)$ & $(0.111)$ & $(0.336)$ \\
\hline
\end{tabular}

Notes: The numbers represent the percentage change in the cumulative probability of university enrolment (within 5 years after high-school graduation) when the expected value (or the variance) of after-tax income for every future year in the paths with or without a university degree is increased by $10 \%$, leaving everything else unchanged, including future income in the alternative path. Division by 10 yields approximate elasticity measures. The numbers in column (1) are calculated by using the estimated structural model with homogeneous risk aversion in column (2) of Table 1, while the other numbers are based on the model with heterogeneous risk aversion in column (5) of Table 1. In columns (3) and (4), simulations are conducted pretending everybody were of type 1 or type 2 , respectively, by using the corresponding risk aversion coefficient $\rho_{j}$. Bootstrapped standard errors in parentheses. Significance levels: * $\mathrm{p}<0.1, * * \mathrm{p}<0.05, * * * \mathrm{p}<0.01$.

Source: Authors' calculations based on the SOEP (sample of high-school graduates), 2000-2010.

High-school graduates of the more risk averse type 2 are more responsive to changes in income risk. When the variance of after-tax income for workers without a university degree increases by $10 \%$ (leaving the expected value unchanged), the probability of university enrolment of type 2 individuals increases by $0.97 \%$ in order to avoid this additional income risk. The enrolment probability does not increase significantly for type 1 . Consistently, when income risk increases for university graduates, type 2 persons decrease their enrolment rate, whereas type 1 does not react significantly. These simulations show that changes in the expected distributions of future after-tax income, which may be caused by tax reforms such as 
the introduction of graduate taxes to finance university education (e.g., Friedman, 1955), will have different effects on enrolment behaviour of different groups depending on their risk preferences.

To conclude the presentation of the results, we provide an illustrative example of an application of our microeconometric model of university enrolment, which demonstrates the implications of the heterogeneity in risk aversion identified. We simulate the effect of a hypothetical introduction of a flat rate income tax schedule on university enrolment rates in Germany. In this tax policy scenario, we assume that the current directly progressive income tax schedule with increasing marginal tax rates of $15-45 \%$ is replaced by a schedule with a single flat tax rate of $26.9 \%$, while the basic tax allowance remains unchanged (the allowance was 7664 euro for single tax filers and double this amount for married joint filers in 2007). In a microsimulation study, Fuest el al. (2008) establish that this tax reform scenario would have been revenue neutral in 2007, and they simulate labour supply responses. ${ }^{24}$ Fossen and Glocker (2011) simulate the effects of this policy scenario on university enrolment of young men and women, but do not allow for heterogeneity with respect to risk aversion. In the following, we use our microsimulation model to re-calculate the first and second moments of future after-tax income that enter the university enrolment model under the hypothetical revenue-neutral flat tax regime and compare the predicted average annual university enrolment rates of potential students (within the first five years after high-school graduation) with the predictions based on the actual directly progressive tax schedule. To have a uniform reference tax policy scenario, we only use the waves from 2005-10 for the simulation, a period in which the German personal income tax schedule remained largely unchanged.

\footnotetext{
${ }^{24}$ The Council of Economic Advisors to the Ministry of Finance (2004) suggested a similar (but not revenueneutral) flat tax system with a basic allowance of 10,000 EUR and a tax rate of $30 \%$.
} 
The results appear in Table 4. Based on model $(5)^{25}$ of Table 1 and using the type probabilities conditional on the observed variables, the hypothetical flat rate tax system would significantly increase the predicted average enrolment probability per year by 6.6 percentage points from $30.2 \%$ to $36.8 \%$. This increase in the enrolment rate should be interpreted as an immediate short term effect of the hypothetical tax reform because the cumulative enrolment probability after five years does not change statistically significantly (not shown in the table). Like before, the implications of the heterogeneity of risk aversion can be studied by running counterfactual simulations where we pretend that everybody in the sample were type 1 (column 2) or the more risk averse type 2 (column 3). While the flat tax policy would significantly increase the average annual enrolment rates of type 1 individuals by even more (7.9 percentage points), the predicted change for the smaller group of highly risk averse persons is very small and insignificant. This can be explained by the fact that the flat rate tax would increase both the expected value and the variance of after-tax income for persons in the higher income range because marginal tax rates would decrease in this range, which is especially relevant for university graduates because of their higher average income. For the more risk averse potential students of type 2, the stronger increase in the variance of after-tax income for university graduates relative to non-graduates offsets the higher relative gain in the expected value of after-tax income brought about by the flat tax. The flat rate tax is attractive only for the less risk averse potential students of type 1 who weigh the relative gain in the expected value of income as a university graduate higher than the relative increase in income risk. The difference in the expected responses of the two types highlights the importance of accounting for heterogeneity in risk aversion when conducting policy simulations.

\footnotetext{
${ }^{25}$ The results are very similar in size and significance if model (4) of Table 1 is used instead (available from the authors on request).
} 
Table 4: Simulated effect of a flat tax policy scenario on the university enrolment probability

\begin{tabular}{|c|c|c|c|}
\hline & \multirow{2}{*}{$\begin{array}{l}\text { Heterogeneous risk aversion } \\
\text { Using actual type probabili- } \\
\text { ties }\end{array}$} & \multicolumn{2}{|c|}{ Counterfactual simulations } \\
\hline & & $\begin{array}{l}\text { Everybody is } \\
\text { type } 1 \text { (low } \\
\text { risk aversion) }\end{array}$ & $\begin{array}{l}\text { Everybody is } \\
\text { type } 2 \text { (high risk } \\
\text { aversion) }\end{array}$ \\
\hline \multicolumn{4}{|l|}{ Baseline progressive tax scenario } \\
\hline Average enrolment probability & $\begin{array}{l}30.18 * * * \\
(1.40)\end{array}$ & $\begin{array}{l}30.12 * * * \\
(1.43)\end{array}$ & $\begin{array}{l}30.81 * * * \\
(1.77)\end{array}$ \\
\hline \multicolumn{4}{|l|}{ Hypothetical flat rate tax scenario } \\
\hline Average enrolment probability & $\begin{array}{l}36.80 * * * \\
(3.14)\end{array}$ & $\begin{array}{l}38.02 * * * \\
(3.39)\end{array}$ & $\begin{array}{l}30.46^{* * * *} \\
(2.48)\end{array}$ \\
\hline Increase in percentage points & $\begin{array}{l}6.62 * * \\
(2.93)\end{array}$ & $\begin{array}{l}7.90 * * \\
(3.08)\end{array}$ & $\begin{array}{l}-0.35 \\
(2.82)\end{array}$ \\
\hline
\end{tabular}

Notes: This table compares the simulated average annual university enrolment probabilities of high school graduates (in the first 5 years after high-school graduation) based on the directly progressive income tax system in Germany (baseline scenario) and on a hypothetical revenue-neutral policy scenario with a flat rate tax of $26.9 \%$ and an unchanged basic tax allowance. The simulations are conducted by applying the estimated structural model with heterogeneous risk aversion in column (5) of Table 1 to high school graduates in the 2005-2010 subsample. In the two rightmost columns, simulations are conducted pretending everybody were of type 1 or type 2 , respectively, by using the corresponding risk aversion coefficient $\rho_{j}$. Bootstrapped standard errors in parentheses. Significance levels: $* \mathrm{p}<0.1, * * \mathrm{p}<0.05, * * * \mathrm{p}<0.01$.

Source: Authors' calculations based on the SOEP (sample of high-school graduates), model estimation based on 2000-2010, simulations based on 2005-2010.

\section{Conclusion}

We estimate a structural microeconometric model of the individual choice of high-school graduates to enter university studies. This decision depends on individually forecasted future after-tax income and its risk in the two alternative paths with and without a university education. Estimating the model based on individual choices allows us to identify revealed risk and time preference parameters. We allow for unobserved heterogeneity and identify two latent classes with different degrees of risk aversion as indicated by different Arrow-Pratt coefficients of constant relative risk aversion. We illustrate the relevance of the distinction between the types by showing that they respond differently to a simulated hypothetical tax policy scenario.

The probability of belonging to one of the two types is modelled as a function of the general willingness to take risks stated by the high-school graduates in the panel survey. We find that those who self-report a low willingness to take risks are more likely to belong to the latent class with the larger risk aversion coefficient revealed from educational choice. This 
indicates consistency between stated and revealed risk preferences and increases confidence in both, the interpretation of the structural Arrow-Pratt parameter as revealed risk preference and the behavioural relevance of the stated survey measure of risk preferences.

We suggest the general approach presented here as a method to assess the relationship between stated survey measures of preferences with structural preference parameters obtained from observed economic choices in the real world with large stakes involved, without exclusively relying on experiments. The approach can be applied for cross-checks in both directions: Stated preferences can be validated by investigating their link to revealed preferences in structural models like the one suggested here, as an alternative or in addition to experiments; and the other way round, structural models used for policy simulations can be linked to stated preferences to reinforce the interpretation of the model parameters as specific preferences, as opposed to reflecting some other, less understood features of the data.

The approach is not limited to risk preferences; future research may consider heterogeneity in time preferences, inequality aversion or other parameters in a similar way. Likewise, the model of university enrolment is an example for a wide range of structural models that could be assessed in this manner, for example labour supply models or models of self-employment or retirement choice. The approach can also be applied to dynamic programming models to take into account the importance of the timing and sequence of choices in labour supply contexts.

\section{References}

Anderberg, D. (2009). Optimal policy and the risk properties of human capital reconsidered. Journal of Public Economics 93(9): 1017-1026.

Anderberg, D. and F. Andersson (2003). Investments in human capital, wage uncertainty, and public policy. Journal of Public Economics 87(7): 1521-1537.

Andersen, S., G. W. Harrison, M. I. Lau and E. E. Rutström (2008). Eliciting risk and time preferences. Econometrica 76(3): 583-618. 
Anderson, L. R. and J. M. Mellor (2008). Predicting health behaviors with an experimental measure of risk preference. Journal of Health Economics 27: 1260-1274.

Carneiro, P., K. T. Hansen and J. J. Heckman (2003). Estimating distributions of treatment effects with an application to the returns schooling and measurement of the effects of uncertainty on college choice. International Economic Review 44(2): 361-422.

Council of Economic Advisors to the Ministry of Finance (2004). Flat Tax oder Duale Einkommensteuer? Zwei Entwürfe zur Reform der deutschen Einkommensbesteuerung. [Flat Tax or Dual Income Tax? Two drafts for a reform of German income taxation.] Berlin: Federal Ministry of Finance.

Cunha, F., J. J. Heckman and S. Navarro (2005). Separating uncertainty from heterogeneity in life cycle earnings. Oxford Economic Papers 57(2): 191-261.

Cunha, F. and J. J. Heckman (2007). Identifying and estimating the distributions of ex post and ex ante returns to schooling. Labour Economics 14(6): 870-893.

Dave, C., C. Eckel, C. Johnson and C. Rojas (2010). Eliciting risk preferences: When is simple better? Journal of Risk and Uncertainty 41(3): 219-243.

Dohmen, T., A. Falk, D. Huffman, U. Sunde, J. Schupp and G. Wagner (2011). Individual risk attitudes: Measurement, determinants, and behavioral consequences. Journal of the European Economic Association 9(3): 522-550.

Eaton, J. and H. S. Rosen (1980). Taxation, human capital, and uncertainty. American Economic Review 70(4): 705-715.

Eckel, C. C. and P. J. Grossman (2002). Sex differences and statistical stereotyping in attitudes toward financial risk. Evolution and Human Behavior 23(4): 281-295.

Eisenhauer, P., J. J. Heckman and S. Mosso (2013). Estimation of dynamic discrete choice models by maximum likelihood and the simulated method of moments. Working paper, University of Chicago, http://www.policy-lab.org/wordpress/wpcontent/uploads/2013/08/simMethods-paper.pdf.

Epstein, L. G. and S. E. Zin (1989). Substitution, risk aversion, and the temporal behavior of consumption and asset returns: A theoretical framework. Econometrica 57(4): 937-969.

Epstein, L. G. and S. E. Zin (1991). Substitution, risk aversion, and the temporal behavior of consumption and asset returns: An empirical analysis. Journal of Political Economy 99(2): 263-286.

Fishe, R. P., R. Trost and P. M. Lurie (1981). Labor force earnings and college choice of young women: An examination of selectivity bias and comparative advantage. Economics of Education Review 1(2): 169-191. 
Fossen, F. M. (2012). Risk attitudes and private business equity. In D. Cumming (ed.): The Oxford Handbook of Entrepreneurial Finance. New York, Oxford University Press: 109132.

Fossen, F. M. and D. Glocker (2011). Expected future earnings, taxation, and university enrollment. International Tax and Public Finance 18(6): 688-723.

French, E. and J. B. Jones (2011). The effects of health insurance and self-insurance on retirement behavior. Econometrica 79(3): 693-732.

Friedman, M. (1955). The role of government in public education. In R. A. Solo (ed.): Economics and the public interest. New Brunswick, University of Rutgers Press.

Fuest, C., A. Peichl and T. Schaefer (2008). Is a flat tax reform feasible in a grown-up democracy of western Europe? A simulation study for Germany. International Tax and Public Finance 15(5): 620-636.

Glocker, D. (2011). The effect of student aid on the duration of study. Economics of Education Review 30(1): 177-190.

Harrison, G. W., J. A. List and C. Towe (2007). Naturally occurring preferences and exogenous laboratory experiments: A case study of risk aversion. Econometrica 75(2): 433-458.

Hartlaub, V. and T. Schneider (2012). Educational choice and risk aversion: How important is structural vs. individual risk aversion? SOEPpapers 433, German Institute for Economic Research (DIW Berlin).

Hartog, J. and L. Diaz-Serrano (2007). Earnings risk and demand for higher education: A cross-section test for Spain. Journal of Applied Economics 10: 1-28.

Hartog, J. and W. P. Vijverberg (2007). On compensation for risk aversion and skewness affection in wages. Labour Economics 14(6): 938-956.

Heckman, J. J. (1978). Dummy endogenous variables in a simultaneous equation system. Econometrica 46(4): 931-959.

Heine, C., H. Spangenberg and J. Willich (2008). Studienberechtigte 2006 ein halbes Jahr nach Schulabschluss - Übergang in Studium, Beruf und Ausbildung. [Potential students 2006 half a year after high-school graduation - The transition to university studies, job and training]. Forum Hochschule, Hochschul Informations System GmbH.

Heublein, U., H. Spangenberg and D. Sommer (2003). Ursachen des Studienabbruchs Analyse 2002. [Causes of university drop-out - Analysis 2002]. Hochschulplanung, Hochschul Informations System GmbH. 
Hogan, V. and I. Walker (2007). Education choice under uncertainty: Implications for public policy. Labour Economics 14(6): 894-912.

Holt, C. A. and S. K. Laury (2002). Risk aversion and incentive effects. American Economic Review 92(5): 1644-1655.

Jenkins, S. P. (1995). Easy estimation methods for discrete-time duration models. Oxford Bulletin of Economics and Statistics 57(1): 129-138.

Keane, M. P. And K. I. Wolpin (2001). The effect of parental transfers and borrowing constraints on educational attainment. International Economic Review 42(4): 1051-1103.

Kodde, D. A. (1986). Uncertainty and the demand for education. Review of Economics and Statistics 68(3): 460-467.

Kreps, D. M. and E. L. Porteus (1978). Temporal resolution of uncertainty and dynamic choice theory. Econometrica 46(1): 185-200.

Levhari, D. and Y. Weiss (1974). The effect of risk on the investment in human capital. American Economic Review 64(6): 950-963.

Levitt, S. D. and J. A. List (2007). What do laboratory experiments measuring social preferences reveal about the real world? Journal of Economic Perspectives 21(2): 153174.

Lusk, J. and K. Coble (2005). Risk perceptions, risk preference, and acceptance of risky food. American Journal of Agricultural Economics 87(2): 393-405.

Maddala, G. S. (1986). Limited-dependent and qualitative variables in econometrics. Cambridge, Cambridge University Press.

McFadden, D. (1973). Conditional logit analysis of qualitative choice behavior. New-York, Academic Press.

OECD (2012). Education at a glance 2012: OECD indicators. OECD Publishing. http://dx.doi.org/10.1787/eag-2012-en.

Pratt, J. W. (1964). Risk aversion in the small and in the large. Econometrica 32(1/2): 122136.

Sauer, R. M. (2004). Educational financing and lifetime earnings. Review of Economic Studies 71(4): 1189-1216.

Vischer, T., T. Dohmen, A. Falk, D. Huffmann, J. Schupp, U. Sunde and G. G. Wagner (2013). Validating an ultra-short survey measure of patience. Economic Letters 120(2): 142-145. 
Voors, M., T. Turley, A. Kontoleon, E. Bulte and J. A. List (2012). Exploring whether behavior in context-free experiments is predictive of behavior in the field: Evidence from lab and field experiments in rural Sierra Leone. Economics Letters 114, 308-311.

Wagner, G. G., J. R. Frick and J. Schupp (2007). The German Socio-economic Panel Study (SOEP)—Scope, evolution and enhancements. Schmollers Jahrbuch - Journal of Applied Social Science Studies 127(1): 139-169.

\section{Appendix}

Table A 1: Descriptive statistics for the samples of high-school graduates

\begin{tabular}{|c|c|c|}
\hline Variable & Mean & Std dev. \\
\hline Eligible for student aid & 0.25 & \\
\hline Parental net monthly labour income (in 1,000 euro) & 2.68 & 1.95 \\
\hline Age when graduated from high school & 19.45 & 1.00 \\
\hline Mother holds university degree & 0.27 & \\
\hline Father holds university degree & 0.35 & \\
\hline Intended a university degree at age 17 & 0.48 & \\
\hline Intended degree at age 17 n.a. & 0.27 & \\
\hline Finished apprenticeship & 0.12 & \\
\hline Graduated from high school in a federal state that charged tuition fees & 0.25 & \\
\hline Respondent has one sibling & 0.17 & \\
\hline Respondent has more than one sibling & 0.03 & \\
\hline \multicolumn{3}{|l|}{ School grade in German at age 17: } \\
\hline n.a. & 0.27 & \\
\hline Very good (1) & 0.04 & \\
\hline Good (2) & 0.28 & \\
\hline Satisfactory (3) & 0.31 & \\
\hline Poor (4-6) & 0.10 & \\
\hline \multicolumn{3}{|l|}{ School grade in math at age 17: } \\
\hline n.a. & 0.27 & \\
\hline Very good (1) & 0.09 & \\
\hline Good (2) & 0.22 & \\
\hline Satisfactory (3) & 0.24 & \\
\hline Poor (4-6) & 0.17 & \\
\hline \multicolumn{3}{|l|}{ Region } \\
\hline North & 0.10 & \\
\hline East & 0.26 & \\
\hline South & 0.22 & \\
\hline West & 0.35 & \\
\hline City state & 0.08 & \\
\hline \multicolumn{3}{|l|}{ Years since high-school graduation: } \\
\hline 1 year & 0.45 & \\
\hline 2 years & 0.26 & \\
\hline 3 years & 0.13 & \\
\hline 4 years & 0.10 & \\
\hline 5 years & 0.06 & \\
\hline Male & 0.49 & \\
\hline Transition to university & 0.29 & \\
\hline General willingness to take risks (scale $0-10$ ) & 5.39 & 1.95 \\
\hline $\mathrm{N}$ & 2287 & \\
\hline
\end{tabular}

Note: Standard deviations are not shown for binary variables.

Source: Authors' calculations based on the SOEP (sample of high-school graduates), 2000-2010. 
Table A 2: Descriptive statistics for the sample of persons at working age

\begin{tabular}{|c|c|c|c|c|}
\hline \multirow[t]{2}{*}{ Variable } & \multicolumn{2}{|l|}{ Men } & \multicolumn{2}{|c|}{ Women } \\
\hline & Mean & Std dev. & Mean & Std dev. \\
\hline \multicolumn{5}{|l|}{ Parental education: } \\
\hline High-school degree & 0.36 & & 0.38 & \\
\hline No high-school degree & 0.60 & & 0.57 & \\
\hline n.a. & 0.04 & & 0.05 & \\
\hline \multicolumn{5}{|l|}{ Last grade in subject German: } \\
\hline Very good (1) & 0.05 & & 0.09 & \\
\hline Good (2) & 0.21 & & 0.25 & \\
\hline Satisfactory (3) & 0.20 & & 0.15 & \\
\hline Poor $(4-6)$ & 0.06 & & 0.04 & \\
\hline n.a. & 0.47 & & 0.48 & \\
\hline \multicolumn{5}{|l|}{ Last grade in subject math: } \\
\hline Very good (1) & 0.11 & & 0.08 & \\
\hline Good (2) & 0.20 & & 0.19 & \\
\hline Satisfactory (3) & 0.15 & & 0.16 & \\
\hline Poor (4-6) & 0.08 & & 0.11 & \\
\hline n.a. & 0.46 & & 0.46 & \\
\hline \multicolumn{5}{|c|}{ Parents show(ed) interest in school performance (at age 15): } \\
\hline Not at all & 0.02 & & 0.02 & \\
\hline Not very much & 0.14 & & 0.16 & \\
\hline Quite a lot & 0.27 & & 0.25 & \\
\hline Very much & 0.11 & & 0.13 & \\
\hline \multicolumn{5}{|l|}{ Place where grew up (at age 15): } \\
\hline Large city (more than 100,000 inh.) & 0.25 & & 0.25 & \\
\hline Medium city $(20,000-100,000$ inh.) & 0.19 & & 0.19 & \\
\hline Small city $(5,000-20,000$ inh. $)$ & 0.23 & & 0.22 & \\
\hline Countryside $(<5,000$ inh. $)$ & 0.28 & & 0.28 & \\
\hline n.a. & 0.06 & & 0.06 & \\
\hline \multicolumn{5}{|l|}{ Father's employment status (at age 15): } \\
\hline working & 0.84 & & 0.83 & \\
\hline unemployed/not working & 0.01 & & 0.01 & \\
\hline other & 0.02 & & 0.02 & \\
\hline n.a. & 0.13 & & 0.14 & \\
\hline \multicolumn{5}{|l|}{ Mother's employment status (at age 15): } \\
\hline working & 0.29 & & 0.33 & \\
\hline unemployed/not working & 0.21 & & 0.17 & \\
\hline other & 0.01 & & 0.01 & \\
\hline n.a. & 0.49 & & 0.49 & \\
\hline \multicolumn{5}{|l|}{ Parental nationality: } \\
\hline Both parents are German & 0.62 & & 0.59 & \\
\hline One parent is German & 0.03 & & 0.03 & \\
\hline Both parents are not German & 0.05 & & 0.05 & \\
\hline n.a. & 0.31 & & 0.33 & \\
\hline No biographical information & 0.45 & & 0.44 & \\
\hline No biographical information of parents & 0.01 & & 0.01 & \\
\hline Working & 0.84 & & 0.72 & \\
\hline Experienced years of unemployment & 0.36 & 1.05 & 0.43 & 1.19 \\
\hline \multicolumn{5}{|l|}{ Further education after high school: } \\
\hline In training (apprenticeship) & 0.02 & & 0.02 & \\
\hline Finished apprenticeship & 0.34 & & 0.28 & \\
\hline Vocational education & 0.24 & & 0.32 & \\
\hline University of applied science & 0.17 & & 0.18 & \\
\hline University degree & 0.63 & & 0.57 & \\
\hline n.a. & 0.00 & & 0.00 & \\
\hline Self-employed liberal professional & 0.05 & & 0.04 & \\
\hline Self-employed in other occupation & 0.05 & & 0.02 & \\
\hline Civil servant & 0.12 & & 0.10 & \\
\hline Age & 41.69 & 12.06 & 39.59 & 11.60 \\
\hline
\end{tabular}


Table A 2 continued

\begin{tabular}{lllll}
\hline Married & 0.60 & & 0.58 & \\
No. of children in household aged 6 and under & 0.18 & 0.48 & 0.20 & 0.48 \\
No. of children in household aged 7 to 16 years & 0.43 & 0.79 & 0.43 & 0.78 \\
Disabled & 0.04 & & 0.04 & \\
Not German born & 0.06 & & 0.06 \\
$\mathrm{~N}$ & 24974 & & 26209 & \\
\hline
\end{tabular}

Note: Standard deviations are not shown for binary variables.

Source: Authors' calculations based on the SOEP, 2000-2010.

Table A 3: Selection equations of educational attainment and work participation: Bivariate probit results

\begin{tabular}{|c|c|c|c|c|}
\hline & \multicolumn{2}{|l|}{ Men } & \multicolumn{2}{|l|}{ Women } \\
\hline & $\begin{array}{l}\text { University } \\
\text { education }\end{array}$ & $\begin{array}{l}\text { Work } \\
\text { participation }\end{array}$ & $\begin{array}{l}\text { University } \\
\text { education }\end{array}$ & $\begin{array}{l}\text { Work } \\
\text { participation }\end{array}$ \\
\hline \multicolumn{5}{|l|}{ Parental education: } \\
\hline High-school degree & $\begin{array}{l}0.069 * * * \\
(0.019)\end{array}$ & & $\begin{array}{l}0.161 * * * \\
(0.019)\end{array}$ & \\
\hline n.a. & $\begin{array}{l}-0.449 * * * \\
(0.053)\end{array}$ & & $\begin{array}{l}-0.213 * * * \\
(0.050)\end{array}$ & \\
\hline \multicolumn{5}{|c|}{ Last grade in subject German (Base: Good (2)): } \\
\hline Very good (1) & $\begin{array}{l}0.282 * * * \\
(0.047)\end{array}$ & & $\begin{array}{l}0.327 * * * \\
(0.034)\end{array}$ & \\
\hline Satisfactory (3) & $\begin{array}{l}-0.078 * * * \\
(0.027)\end{array}$ & & $\begin{array}{l}-0.111 * * * \\
(0.027)\end{array}$ & \\
\hline Poor (4-6) & $\begin{array}{l}-0.090 * * \\
(0.041)\end{array}$ & & $\begin{array}{l}-0.257 * * * \\
(0.055)\end{array}$ & \\
\hline n.a. & $\begin{array}{l}0.038 \\
(0.079)\end{array}$ & & $\begin{array}{l}-0.116^{*} \\
(0.060)\end{array}$ & \\
\hline \multicolumn{5}{|c|}{ Last grade in subject math (Base: Good (2)): } \\
\hline Very good (1) & $\begin{array}{l}0.272 * * * \\
(0.035)\end{array}$ & & $\begin{array}{l}0.218 * * * \\
(0.035)\end{array}$ & \\
\hline Satisfactory (3) & $\begin{array}{l}-0.147 * * * \\
(0.029)\end{array}$ & & $\begin{array}{l}-0.244 * * * \\
(0.028)\end{array}$ & \\
\hline Poor (4-6) & $\begin{array}{l}-0.375^{* * *} * \\
(0.036)\end{array}$ & & $\begin{array}{l}-0.198 * * * \\
(0.032)\end{array}$ & \\
\hline n.a. & $\begin{array}{l}0.064 \\
(0.095)\end{array}$ & & $\begin{array}{l}-0.175^{* *} \\
(0.080)\end{array}$ & \\
\hline \multicolumn{5}{|c|}{ Parents show(ed) interest in school performance (at age 15) (Base: Quite a lot): } \\
\hline Not at all & $\begin{array}{l}-0.132 * \\
(0.073)\end{array}$ & & $\begin{array}{l}0.105^{*} \\
(0.062)\end{array}$ & \\
\hline Not very much & $\begin{array}{l}0.089 * * * \\
(0.028)\end{array}$ & & $\begin{array}{l}0.185 * * * \\
(0.027)\end{array}$ & \\
\hline Very much & $\begin{array}{l}0.007 \\
(0.030)\end{array}$ & & $\begin{array}{l}0.114 * * * \\
(0.028)\end{array}$ & \\
\hline n.a. & $\begin{array}{l}0.123 \\
(0.111)\end{array}$ & & $\begin{array}{l}-0.502 * * * \\
(0.101)\end{array}$ & \\
\hline \multicolumn{5}{|c|}{ Place where grew up (at age 15) (Base: Large city (>100,000 inh.): } \\
\hline Medium city (20000-100000 inh.) & $\begin{array}{l}-0.090 * * * \\
(0.026)\end{array}$ & & $\begin{array}{l}-0.112 * * * \\
(0.025)\end{array}$ & \\
\hline Small city (5000-20000 inh.) & $\begin{array}{l}-0.060 * * \\
(0.024)\end{array}$ & & $\begin{array}{l}0.015 \\
(0.024)\end{array}$ & \\
\hline Countryside (<5000 inh.) & $\begin{array}{l}-0.060 * * \\
(0.024)\end{array}$ & & $\begin{array}{l}-0.111 * * * \\
(0.023)\end{array}$ & \\
\hline n.a. & $\begin{array}{l}0.190 * * * \\
(0.045)\end{array}$ & & $\begin{array}{l}-0.004 \\
(0.044)\end{array}$ & \\
\hline
\end{tabular}




\begin{tabular}{|c|c|c|c|c|}
\hline \multicolumn{5}{|c|}{ Father's employment status (at age 15) (Base: working): } \\
\hline \multirow[t]{2}{*}{ unemployed } & $-0.959 * * *$ & & $-0.905 * * *$ & \\
\hline & $(0.118)$ & & $(0.091)$ & \\
\hline \multirow[t]{2}{*}{ other } & $-0.366 * * *$ & & $-0.263 * * *$ & \\
\hline & $(0.062)$ & & $(0.064)$ & \\
\hline \multirow[t]{2}{*}{ n.a. } & -0.010 & & $-0.270 * * *$ & \\
\hline & $(0.030)$ & & $(0.027)$ & \\
\hline \multicolumn{5}{|c|}{ Mother's employment status (at age 15) (Base: working): } \\
\hline \multirow[t]{2}{*}{ not working } & $0.484 * * *$ & & $0.282 * * *$ & \\
\hline & $(0.025)$ & & $(0.025)$ & \\
\hline \multirow[t]{2}{*}{ other } & $-1.333 * * *$ & & $-1.122 * * *$ & \\
\hline & $(0.141)$ & & $(0.114)$ & \\
\hline \multirow[t]{2}{*}{ n.a. } & $-0.188 * * *$ & & $-0.347 * * *$ & \\
\hline & $(0.046)$ & & $(0.044)$ & \\
\hline \multicolumn{5}{|c|}{ Parents' nationality (Base: at least one parent is German): } \\
\hline \multirow[t]{2}{*}{ not German born } & -0.057 & & $0.118 * * *$ & \\
\hline & $(0.044)$ & & $(0.040)$ & \\
\hline \multirow[t]{2}{*}{ n.a. } & $0.629 * * *$ & & $0.676 * * *$ & \\
\hline & $(0.027)$ & & $(0.028)$ & \\
\hline \multirow[t]{2}{*}{ No biographical information } & $-0.384 * * *$ & & $0.904 * * *$ & \\
\hline & $(0.130)$ & & $(0.126)$ & \\
\hline \multirow[t]{2}{*}{ No biographical information on Parents } & $-0.356 * * *$ & & -0.172 & \\
\hline & $(0.117)$ & & $(0.115)$ & \\
\hline \multirow[t]{2}{*}{ Age } & & $0.328 * * *$ & & $0.291 * * *$ \\
\hline & & $(0.007)$ & & $(0.007)$ \\
\hline \multirow[t]{2}{*}{ Age squared } & & $-0.004 * * *$ & & $-0.003 * * *$ \\
\hline & & $(0.000)$ & & $(0.000)$ \\
\hline \multirow[t]{2}{*}{ Married } & & $0.203 * * *$ & & $-0.221 * * *$ \\
\hline & & $(0.034)$ & & $(0.024)$ \\
\hline \multirow[t]{2}{*}{ No. of children in household aged 6 and under } & & $0.175 * * *$ & & $-0.845 * * *$ \\
\hline & & $(0.038)$ & & $(0.021)$ \\
\hline \multirow[t]{2}{*}{ No. of children in househ. aged 7 to 16 years } & & -0.031 & & $-0.260 * * *$ \\
\hline & & $(0.020)$ & & $(0.013)$ \\
\hline \multirow[t]{2}{*}{ Not German born } & & $-0.226 * * *$ & & $-0.383 * * *$ \\
\hline & & $(0.050)$ & & $(0.038)$ \\
\hline \multicolumn{5}{|l|}{ Experienced years of ... since first started working: } \\
\hline \multirow[t]{2}{*}{ Unemployment } & & $-0.425 * * *$ & & $-0.251 * * *$ \\
\hline & & $(0.017)$ & & $(0.017)$ \\
\hline Unemployment squared & & $0.018 * * *$ & & $0.013 * * *$ \\
\hline & & $(0.002)$ & & $(0.002)$ \\
\hline Disabled & & $-0.207 * * *$ & & 0.004 \\
\hline & & $(0.057)$ & & $(0.052)$ \\
\hline Respondent has university degree & & 0.120 & & $0.338 * * *$ \\
\hline & & $(0.116)$ & & $(0.096)$ \\
\hline Federal State dummies & & yes & & yes \\
\hline Year dummies & & yes & & yes \\
\hline Constant & $0.304 * * *$ & $-5.571 * * *$ & $0.101 * * *$ & $-4.881 * * *$ \\
\hline & $(0.033)$ & $(0.162)$ & $(0.031)$ & $(0.128)$ \\
\hline Correlation coefficient $\rho$ & $0.148 * *$ & & -0.018 & \\
\hline & $(0.071)$ & & $(0.060)$ & \\
\hline$\chi^{2}$ & 5467.837 & & 5856.948 & \\
\hline $\mathrm{N}$ & 24389 & & 25656 & \\
\hline
\end{tabular}

Notes: For each gender, the two selection equations of having a university degree and of work participation are estimated jointly using a bivariate probit model, which allows for a structural shift by including the university education dummy in the work participation equation. Robust standard errors in parentheses. Significance levels: * $\mathrm{p}<0.1, * * \mathrm{p}<0.05, * * * \mathrm{p}<0.01$.

Source: Authors' calculations based on the SOEP, 2000-2010. 
Table A 4: Regression of before-tax wages

\begin{tabular}{|c|c|c|c|c|}
\hline & \multicolumn{2}{|l|}{ Men } & \multicolumn{2}{|l|}{ Women } \\
\hline & $\begin{array}{l}\text { University } \\
\text { graduates }\end{array}$ & $\begin{array}{l}\text { Non-university } \\
\text { graduates }\end{array}$ & $\begin{array}{l}\text { University } \\
\text { graduates }\end{array}$ & $\begin{array}{l}\text { Non-university } \\
\text { graduates }\end{array}$ \\
\hline \multirow[t]{2}{*}{ Work experience } & $0.150 * *$ & $0.167 *$ & $0.342 * * *$ & $0.330 * * *$ \\
\hline & $(0.071)$ & $(0.093)$ & $(0.056)$ & $(0.057)$ \\
\hline \multirow[t]{2}{*}{ Work experience squared } & 0.002 & 0.001 & $-0.005 * * *$ & $-0.006 * * *$ \\
\hline & $(0.002)$ & $(0.003)$ & $(0.002)$ & $(0.002)$ \\
\hline \multicolumn{5}{|c|}{ Education (Base: no further education after high-school): } \\
\hline \multirow[t]{2}{*}{ Finished apprenticeship } & $-2.060 * * *$ & -0.433 & $-1.679 * * *$ & $1.053 * * *$ \\
\hline & $(0.600)$ & $(0.722)$ & $(0.437)$ & $(0.365)$ \\
\hline \multirow[t]{2}{*}{ In training (apprenticeship) } & 0.000 & $-5.531 * * *$ & 0.000 & $-5.012 * * *$ \\
\hline & (.) & $(0.562)$ & (.) & $(0.371)$ \\
\hline \multirow[t]{2}{*}{ Univers. of applied science } & $-1.933 * * *$ & 0.000 & $-2.394 * * *$ & 0.000 \\
\hline & $(0.561)$ & (.) & $(0.357)$ & (.) \\
\hline \multirow[t]{2}{*}{ Vocational education } & $-2.972 * * *$ & 1.460 & $-2.806^{* * *}$ & $0.656^{*}$ \\
\hline & $(0.650)$ & $(0.888)$ & $(0.383)$ & $(0.371)$ \\
\hline \multirow[t]{2}{*}{ n.a. } & 0.253 & 1.566 & $-6.155^{* * *}$ & $-3.685 * * *$ \\
\hline & $(3.292)$ & $(2.264)$ & $(1.091)$ & $(1.118)$ \\
\hline \multirow[t]{2}{*}{ Not German born } & $-2.873 * *$ & $-1.923 * *$ & $-2.110^{*}$ & $-0.962 *$ \\
\hline & $(1.206)$ & $(0.889)$ & $(1.266)$ & $(0.534)$ \\
\hline \multirow[t]{2}{*}{ Self-employed professional } & $9.290 * * *$ & 1.970 & $7.292 * * *$ & $3.257 * *$ \\
\hline & $(1.490)$ & $(2.605)$ & $(1.528)$ & $(1.455)$ \\
\hline \multirow[t]{2}{*}{ Self-employed (other) } & 2.556 & 2.082 & -1.321 & $3.082 * *$ \\
\hline & $(2.003)$ & $(1.583)$ & $(1.104)$ & $(1.409)$ \\
\hline \multirow[t]{2}{*}{ Civil servant } & $-3.208 * * *$ & 0.038 & $2.136 * * *$ & $2.330 * * *$ \\
\hline & $(0.569)$ & $(0.786)$ & $(0.422)$ & $(0.477)$ \\
\hline Regional dummies & yes & yes & yes & yes \\
\hline Year dummies & yes & yes & yes & yes \\
\hline Industrial dummies & yes & yes & yes & yes \\
\hline \multirow[t]{2}{*}{ M12 } & $-3.422 * * *$ & & $-3.603 * * *$ & \\
\hline & $(1.322)$ & & $(0.822)$ & \\
\hline \multirow[t]{2}{*}{ M21 } & $-19.735 * * *$ & & $-3.704 * * *$ & \\
\hline & $(2.038)$ & & $(0.938)$ & \\
\hline \multirow[t]{2}{*}{ M34 } & & 1.629 & & 0.539 \\
\hline & & (1.190) & & $(0.572)$ \\
\hline \multirow[t]{2}{*}{ M43 } & & $-6.507 * * *$ & & $-2.240 * * *$ \\
\hline & & $(0.732)$ & & $(0.741)$ \\
\hline \multirow[t]{2}{*}{ Constant } & $33.730 * * *$ & $17.024 * * *$ & $23.563 * * *$ & $14.917 * * *$ \\
\hline & $(1.295)$ & $(1.546)$ & $(1.149)$ & $(0.890)$ \\
\hline Mean outcome (wage) & 24.979 & 16.627 & 18.274 & 12.470 \\
\hline$R^{2}$ & .1400 & .1828 & .1505 & .2928 \\
\hline $\mathrm{N}$ & 14373 & 6259 & 11851 & 6616 \\
\hline
\end{tabular}

Notes: The wage regressions include the selection correction terms M12, M21, M34 and M43, which are obtained after estimation of the bivariate selection equations (Table A 3). Robust standard errors in parentheses. Significance levels: $* \mathrm{p}<0.1, * * \mathrm{p}<0.05$, *** $\mathrm{p}<0.01$.

Source: Authors' calculations based on the SOEP, 2000-2010. 
Table A 5: Regression of the log variance of before-tax wages

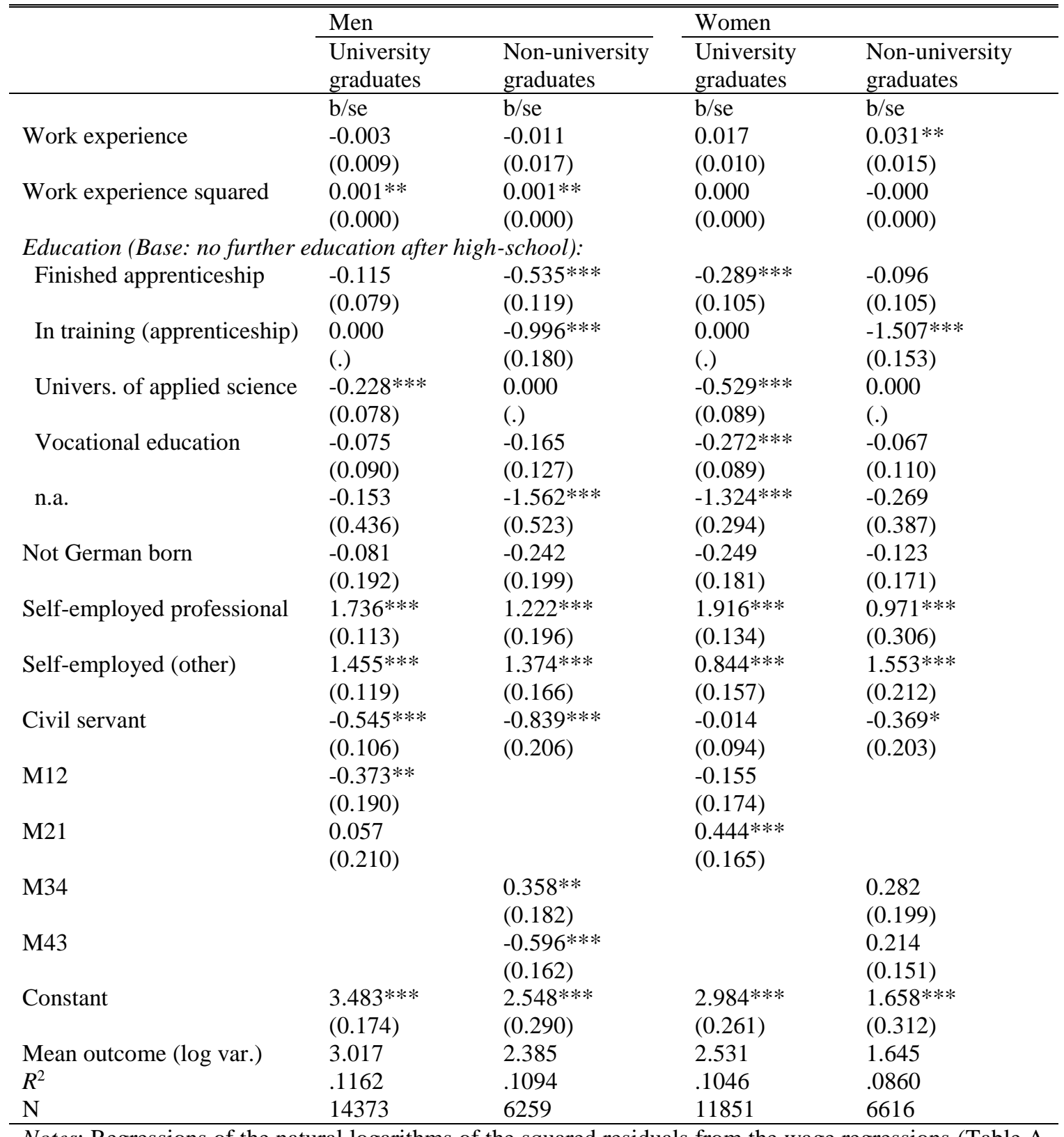

Notes: Regressions of the natural logarithms of the squared residuals from the wage regressions (Table A 4) on explanatory variables including the selection correction terms M12, M21, M34 and M43, which are obtained after estimation of the bivariate selection equations (Table A 3). Robust standard errors in parentheses. Significance levels: $* \mathrm{p}<0.1, * * \mathrm{p}<0.05$, *** $\mathrm{p}<0.01$.

Source: Authors' calculations based on the SOEP, 2000-2010. 